\title{
Synthesis, Characterization and Metal Ion Chelating Efficiency of an Environment-Friendly Copolymers Containing Dithio Formic Acid and Thiosemicarbazide or 1,2,4-Triazole Group
}

\author{
Ayad Hameed \\ Department of Chemistry, College of Science, Tikrit University, Tikrit, Iraq \\ Email: ayad_hameed@yahoo.com
}

Received January 5, 2013; revised February 8, 2013; accepted February 19, 2013

\begin{abstract}
Six phenolic monomers $\left(\mathrm{M}_{1}-\mathrm{M}_{6}\right)$ have been synthesized, namely, potassium-3-(ortho,para)-hydroxy benzoyl dithioformate $\left(\mathrm{M}_{1}\right.$ and $\left.\mathrm{M}_{2}\right)$, (ortho,para)-(4-amino-5-mercapto-1,2,4 triazol-3-yl)-phenol $\left(\mathrm{M}_{3}\right.$ and $\mathrm{M}_{4}$ ), (ortho,para)-hydroxy benzoic acid thiosemicarbazide $\left(\mathrm{M}_{5}\right.$ and $\left.\mathrm{M}_{6}\right)$ and twelve novel chelating terpolymers $\left(\mathrm{P}_{1}-\mathrm{P}_{12}\right)$ were synthesized by terpolymerization condensation reaction of these monomers with phenol or bis phenol-A and excess of formalin in basic medium. The monomers $\left(\mathrm{M}_{1}-\mathrm{M}_{6}\right)$ and their co-polymers $\left(\mathrm{P}_{1}-\mathrm{P}_{12}\right)$ were characterized by FT.IR, $\mathrm{H}^{1}$-NMR, elemental analysis and thermal analysis (TGA) and according to data obtained the structures of these compounds were proposed. Analytical evaluation of chelating selectivity of these polymers toward $\left(\mathrm{Co}^{2+}, \mathrm{Cr}^{3+}, \mathrm{Cu}^{2+}, \mathrm{Cd}^{2+}, \mathrm{Pb}^{2+}\right)$ were achieved by batch equilibrium method, the results show that all synthetic resins have high efficiency toward $\left(\mathrm{Cr}^{3+}\right)$ and less efficiency toward $\left(\mathrm{Co}^{2+}, \mathrm{Cu}^{2+}, \mathrm{Cd}^{2+}\right.$ and $\left.\mathrm{Pb}^{2+}\right)$.
\end{abstract}

Keywords: Organic Terpolymers; Chelating Resin; Thermal Studies

\section{Introduction}

Organic polymers containing coordinating sites is of relatively recent origin and an interdisciplinary approach taking into its world areas viz, chemistry, metallurgys, environmental and material sciences [1,2]. Environmental pollution has become one of the most important problems threating our world [3]. Heavy metal ions remain a serious environmental problem facing the world for water pollution because of the use of metal ions as catalyst in various industries process [4,5]. Chelating polymers have been widely utilized for removal of the undesired heavy metal ions from waste water [6-8]. Phenol resole are the most useful thermosetting materials for the manufacture of composite panels, and have a unique properties such as, solid insoluble, rigid materials with a high fire resistance, longtime thermal and mechanical strength, low toxic and insulating properties $[1,9,10]$. Finally, dithio formic acid, thiosem-icarbazide and 1,2,4triazole groups may act as a good ligands through the nitrogen, oxygen and sulfur atoms, so far no resin based on these functional groups has been reported for the removal of transition metal ions, in view of the above facts, the aim of the present work reveals that design and synthesis of some new phenol resins containing the men- tioned functional groups which were achivied according to Scheme 1, and we hope that the introduction of these three systems as a bending groups on backbone of phenolic resin may increase the selectivity of these chelating resin to remove the heavy metal ions from waste water sample.

\section{Experimental}

\subsection{Materials}

Chemical used in this work were supplied by different companies as follows: Hydrazine hydrate $(80 \%, 99 \%)$, $\mathrm{CS}_{2}$, from Thomas Baker Co., formaldehyde solution (37\%), from Fluka Co. Phenol, Bis phenol-A, from Merck Co. $\boldsymbol{p}$-hydroxy benzoyl hydrazine and $\boldsymbol{o}$-hydroxy benzoyl hydrazine were prepared through refluxing the corresponding ester with hydrazine hydrate. Solutions $(200 \mathrm{ppm})$ of metal ions such as $\left(\mathrm{Co}^{2+}, \mathrm{Cr}^{3+}, \mathrm{Cu}^{2+}, \mathrm{Cd}^{2+}\right.$ and $\mathrm{Pb}^{2+}$ ) were prepared by dilution of stock solution of $(1000 \mathrm{ppm})$ of their nitrate salts in double distilled water.

\subsection{Apparatus}

All melting points were determined on Electro thermal melting point Apparatus Sartorius BL-2105 and are un- 


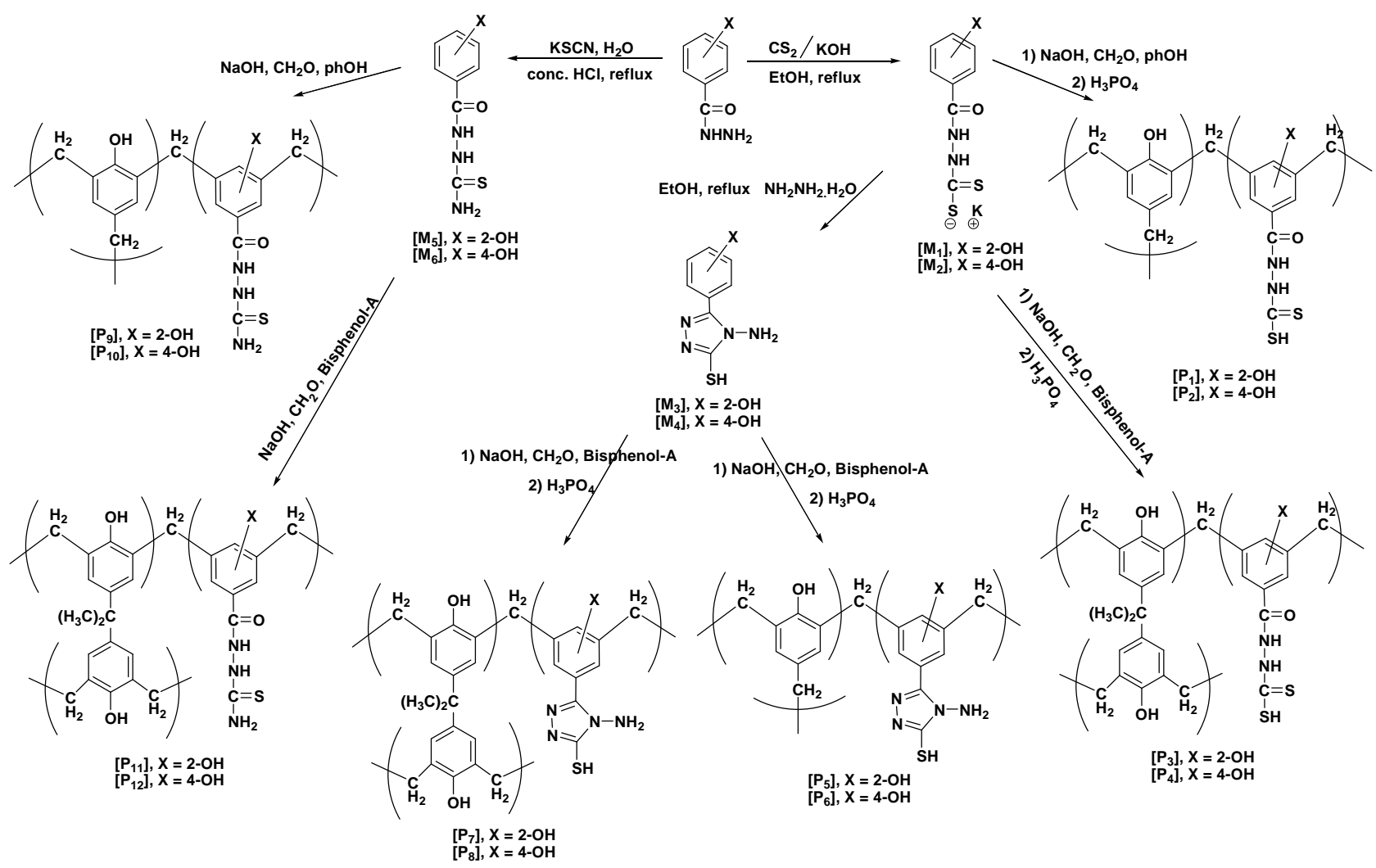

Scheme 1. Synthetic tree for synthesizing the target chelating polymers $\left(P_{1}-P_{12}\right)$.

corrected. The IR-Spectra ( $\mathrm{KBr}$ disks) were taken on a Shimatzu 8400. The H1-NMR Spectra were measured on Bruker-NMR, ultra shield (300) MHZ, Switzerland spectrometer using DMSO-d6 as solvent and TMS as internal reference. Combustion analysis $(\mathrm{C}, \mathrm{H}, \mathrm{N}, \mathrm{S}$.) was performed on Carlo Erba EA-3200 Elemental Analysis.

Thermal analysis curves (TGA) of the polymers sample, which were taken on Shimatzu thermoanalysis model 2145. Loading capacity of the prepared resins toward metal ions are evaluated analytically using Shimatzu model 2800 atomic absorption spectrophotometer.

\subsection{Organic Synthesis}

For the synthesis of the target co polymers $\left(\mathrm{p}_{1}-\mathrm{p}_{12}\right)$, the following sequence of reaction steps was followed as shown in Scheme 1.

\subsubsection{Synthesis of Potassium 2-Hydroxy Benzoyl Hydrazine Dithioformate [ $\left.\mathbf{M}_{1}\right]$ [11]}

In the reaction vessel were charged $(0.05 \mathrm{~mol}, 7.6 \mathrm{gm})$ of salicylic acid hydrazide, $(0.05 \mathrm{~mol}, 2.8 \mathrm{gm})$ of $\mathrm{KOH}$ in (100) $\mathrm{ml}$ of absolute ethanol, $(0.05 \mathrm{~mol})(3 \mathrm{ml})$ of $\mathrm{CS}_{2}$ added gradually in cold ice bath. After all $\mathrm{CS}_{2}$ added the mixture stirred for (10) hours using magnetic stirrer. The salt formed, filtered and dried, and was employed without further purification:
Yield $80 \%$; M.P. $242^{\circ} \mathrm{C}$ (Dec.); IR $\left(\mathrm{KBr}, \mathrm{cm}^{-1}\right), 3261$ (O-H and/or N-H str. vib.), 3074 (C-H aromatic), 1641 $(\mathrm{C}=\mathrm{O}), 1606,1476(\mathrm{C}=\mathrm{C}$ aromatic $), 1335(\mathrm{C}=\mathrm{S}), 739$ (C-H out of plan bending of ortho disub. benzene ); HNMR, $\delta$ : $2.5(1 \mathrm{H}, \mathrm{s},-\mathrm{NH}-\mathrm{CS}-), 7.9$ (1H, s, -CO-NH-), 6.9, 7.3, 7.0, 7.9 (4H, m, Ar-H);

Combustion analysis $(\mathrm{C}, \mathrm{H}, \mathrm{N}$ and $\mathrm{S})$ for $\mathrm{C}_{8} \mathrm{H}_{7} \mathrm{~N}_{2} \mathrm{O}_{2} \mathrm{~S}_{2} \mathrm{~K}$ (\%):

Calculated: $(\mathrm{C}=36.06, \mathrm{H}=2.65, \mathrm{~N}=10.51, \mathrm{~S}=$ 24.07).

Found: $(\mathrm{C}=36.57, \mathrm{H}=2.32, \mathrm{~N}=10.59, \mathrm{~S}=24.99)$.

\subsubsection{Synthesis of Potassium p-Hydroxy Benzoyl Dithio Formate $\left[\mathbf{M}_{2}\right]$}

This compound was prepared in the same way with refluxing time (12 hr).

Yield $78 \%$; M.P. $270^{\circ} \mathrm{C}$ (Dec.); IR (KBr, $\mathrm{cm}^{-1}$ ): 3382 (O-H and/or N-H str. vib), 3080 (C-H aromatic), 1650 $(\mathrm{C}=\mathrm{O}), 1331(\mathrm{C}=\mathrm{S}), 856(\mathrm{C}-\mathrm{H}$ bend. out of plan of paradisub. benzene); $\mathrm{H}^{1}$-NMR $\delta: 2.5(1 \mathrm{H}, \mathrm{s}, \mathrm{NH}-\mathrm{CS}-), 7.7$ $(1 \mathrm{H}, \mathrm{s}, \mathrm{CO}-\mathrm{NH}-), 7.7(2 \mathrm{H}, \mathrm{d}, \mathrm{Ar}-\mathrm{H}), 6.8(2 \mathrm{H}, \mathrm{d}, \mathrm{Ar}-\mathrm{H})$;

Combustion analysis $\left(\mathrm{C}, \mathrm{H}, \mathrm{N}\right.$ and $\mathrm{S}$ ) for $\mathrm{C}_{8} \mathrm{H}_{7} \mathrm{~N}_{2} \mathrm{O}_{2} \mathrm{~S}_{2} \mathrm{~K}$ (\%):

Calculated: $(\mathrm{C}=36.06, \mathrm{H}=2.65, \mathrm{~N}=10.51, \mathrm{~S}=$ 24.07)

Found: $\mathrm{C}=36.57, \mathrm{H}=2.44, \mathrm{~N}=10.33, \mathrm{~S}=24.7$. 


\subsubsection{Synthesis of 2-(4-Amino-5-mercapto-1,2,4- triazol-3-yl)-phenol [ $\left.\mathbf{M}_{3}\right]$ (11)}

A suspension of $(0.01) \mathrm{mol}(2.65 \mathrm{gm})$ of the potassium salt $\left[\mathrm{M}_{1}\right]$ dissolved in (2) $\mathrm{ml}$ of $\mathrm{H}_{2} \mathrm{O}, 0.02 \mathrm{~mol}(1.5 \mathrm{ml})$ of $95 \%$ hydrazine hydrate was refluxed with stirring for 5 hours. The color of the reaction mixture changed to green, hydrogen sulfide was evolved. The mixture added to 100 $\mathrm{ml}$ of crushed ice with stirring and acidification with concentrated hydrochloric acid precipitated a solid. The phenolic triazole was filtered washed with cold water and recrystallized from ethanol to afford the title compound.

Yield 50\%; M .P. $(165-168)^{\circ} \mathrm{C}($ dec. $)$; IR $\left(\mathrm{KBr}, \mathrm{cm}^{-1}\right)$ : 3294, 3190 (N-H), $3029(\mathrm{C}-\mathrm{H})$ aromatic, 2761 (S-H), $1615(\mathrm{C}=\mathrm{N}), 1581,1541,1504$ (aromatic skeleton), 1246 $(\mathrm{N}-\mathrm{N}=\mathrm{C}$ ), 746 (out of plan bending vibration of ortho disubs. benzene); $\mathrm{H}^{1}$-NMR $\delta$ : 6.9, 6.95, 7.01, $7.35(4 \mathrm{H}$, m, Ar-H), 2.5 (2H, s, $\left.\mathrm{NH}_{2}\right), 5.6(1 \mathrm{H}, \mathrm{s}, \mathrm{O}-\mathrm{H})$; (\%):

Combustion analysis $(\mathrm{C}, \mathrm{H}, \mathrm{N}$ and $\mathrm{S})$ for $\mathrm{C}_{8} \mathrm{H}_{8} \mathrm{~N}_{4} \mathrm{OS}$

Calculated: $(\mathrm{C}=46.13, \mathrm{H}=3.87, \mathrm{~N}=26.90$ and $\mathrm{S}=$ 15.39)

Found: $(\mathrm{C}=46.67, \mathrm{H}=3.31, \mathrm{~N}=26.73, \mathrm{~S}=15.77)$.

\subsubsection{Synthesis of 4-(4-Amino-5-mercapto-1,2,4- triazol-3yl)-phenol [ $\left.\mathbf{M}_{4}\right]$}

This compound was prepared in the same way with refluxing time ( $8 \mathrm{hr}$.).

Yield 50\%; M.P. $(257-260)^{\circ} \mathrm{C}$ (dec.); IR $\left(\mathrm{KBr}, \mathrm{cm}^{-1}\right)$ : 3280, $3179(\mathrm{~N}-\mathrm{H}), 2590(\mathrm{~S}-\mathrm{H}), 1612(\mathrm{C}=\mathrm{N}), 1549,1507$ (aromatic skelton), $1225(\mathrm{~N}-\mathrm{N}=\mathrm{C}), 840$ (bending vibration of para-disub benzene) $\mathrm{H}^{1}-\mathrm{NMR} \delta$ : $7.68(2 \mathrm{H}, \mathrm{d}, \mathrm{Ar}-$ H), $6.8(2 \mathrm{H}, \mathrm{d}, \mathrm{Ar}-\mathrm{H}), 5.7(1 \mathrm{H}, \mathrm{s}, \mathrm{O}-\mathrm{H}), 3.5(1 \mathrm{H}, \mathrm{s}, \mathrm{S}-\mathrm{H})$, $2.5\left(2 \mathrm{H}, \mathrm{s}, \mathrm{NH}_{2}\right)$; $(\%)$ :

Combustion analysis $(\mathrm{C}, \mathrm{H}, \mathrm{N}$ and $\mathrm{S})$ for $\mathrm{C}_{8} \mathrm{H}_{8} \mathrm{~N}_{4} \mathrm{OS}$

Calculated: $(\mathrm{C}=46.13, \mathrm{H}=3.87, \mathrm{~N}=26.90, \mathrm{~S}=$ 15.39)

Found: $(\mathrm{C}=46.01, \mathrm{H}=3.64, \mathrm{~N}=26.81, \mathrm{~S}=15.11)$

\subsubsection{Synthesis of o-Hydroxy Benzoic Acid Thiosemicarbazide $\left[\mathrm{M}_{5}\right]$ [12]}

$O$-hydroxy benzoic acid hydrazide (0.01 mole, $1.52 \mathrm{gm})$, conc. hydrochloric acid $(2 \mathrm{ml})$, potassium thiocyanate $(0.02 \mathrm{~mol}, 1.96 \mathrm{gm})$ and $(20 \mathrm{ml})$ water were refluxed for ( $3 \mathrm{hrs}$ ). The reaction mixture was cooled and kept overnight.

The solid was filtered, washed with cold water and crystallized from ethanol to afford the title compound; the physical and spectral data of this compound are as follows:

Yield 62\%; M. P. $(210-213)^{\circ} \mathrm{C}$; IR $\left(\mathrm{KBr}, \mathrm{cm}^{-1}\right): 3199$ (O-H and/or N-H str. vib.), 3438, $3388\left(\mathrm{NH}_{2}\right), 1650$ (C= O), 1606, $1541(\mathrm{C}=\mathrm{C}$ aromatic $), 1352(\mathrm{C}=\mathrm{S}), 750(\mathrm{C}-\mathrm{H}$ out of plane bending ortho disub. benzene).

\subsubsection{Syntheses of $\boldsymbol{p}$-Hydroxy Benzoic Acid Thiosemicarbazide $\left[\mathbf{M}_{6}\right]$}

This compound was prepared in the same way.

Yield 58\%; M. P. $(235-237)^{\circ} \mathrm{C}$; IR $\left(\mathrm{KBr}, \mathrm{cm}^{-1}\right)$ : (3386, 3328) N-H, 3043 (C-H aromatic), $1643(\mathrm{C}=\mathrm{O})$, $1606(\mathrm{C}=\mathrm{C}$ aromatic), $1386(\mathrm{C}=\mathrm{S}), 840$ ( $\mathrm{C}-\mathrm{H}$ out of plane bending of para disub. benzene).

\subsection{Synthesis of Terpolymers [13] $\left[P_{1}-P_{12}\right]$}

\subsubsection{Polymer 1}

Synthesis of (phenol-2-hydroxy benzoyl hydrazine dithio formic acid-formaldehyde], P1.

The reaction vessel was charaged with $(0.02 \mathrm{~mol}, 5.32$ gm) of potassium 2-hydroxy benzoyl hydrazine dithioformate mixed with $(0.02 \mathrm{~mol}, 1.88 \mathrm{gm})$ of phenol and $(30 \mathrm{ml})$ of formaldehyde solution $37 \%$, the $5 \%$ of $\mathrm{NaOH}$ solution added continuously in order to control the $\mathrm{pH}$. of the reaction mixture to $(9.5-10)$.

The reaction vessel was heated to $(90-95)^{\circ} \mathrm{C}$ on oil bath for (3) hours with stirring. After completing, the reaction mixture was transfer to a beaker and cooled, acidified to $\mathrm{pH}=7.5$ by adding $5 \%$ of $\mathrm{H}_{3} \mathrm{PO}_{4}$. The mixture solvent or the liquid has evaporated at $\left(120^{\circ} \mathrm{C}\right)$. The solid compound washed with de-ionized water several times and dried. The solid mass was then crushed to (50 70) mesh size particles as needed and washed with (150 $\mathrm{ml})$ of cold methanol and finally with $(100 \mathrm{ml})$ of hot double distilled water to removed unreacted monomer.

The resin was dried in vacuum oven at $120^{\circ} \mathrm{C}$. The physical and spectral data of this resin are as follow.

IR- $v \mathrm{~cm}^{-1}$; 3415 (O-H emerged with N-H), 3009 (Ar$\mathrm{H}), 2921,2894$ (C-H for methylene linkage), $1641(\mathrm{C}=\mathrm{O})$, 1610, 1477 (aromatic skelton), $1350(\mathrm{C}=\mathrm{S}), 1018(\mathrm{C}-\mathrm{H})$ bending vibration of tetra substituted benzene).

Combustion analysis $\left(\mathrm{C}, \mathrm{H}, \mathrm{N}\right.$ and $\mathrm{S}$ ) for $\mathrm{C}_{18} \mathrm{H}_{17} \mathrm{~N}_{2} \mathrm{O}_{3} \mathrm{~S}_{2}$ (\%):

Calculated: $(\mathrm{C}=57.89, \mathrm{H}=4.55, \mathrm{~N}=7.49, \mathrm{~S}=17.17)$

Found: $(\mathrm{C}=58.33, \mathrm{H}=4.62, \mathrm{~N}=7.51, \mathrm{~S}=17.89)$

The terpolymers $\left[\mathrm{P}_{2}-\mathrm{P}_{12}\right]$ were synthesized following the same procedure as in above and spectral data of these polymers are as follows.

\subsubsection{Polymer 2}

(Phenol, p-hydroxy benzoyl hydrazine dithioformic acid, formaldehyde).

Color: dark brown

IR- $v \mathrm{~cm}^{-1} ; 3360$ (O-H emerged with N-H), 3087 (Ar$\mathrm{H}), 2921,2877$ (C-H for methylene linkage), $1641(\mathrm{C}=\mathrm{O})$, 1606, 1477 (aromatic skelton), 1018 (C-H) bending vibration of tetra substituted benzene).

\subsubsection{Polymer 3}

(Bis phenol-A, 2-hydroxy benzoyl hydrazine dithioformic acid, formaldehyde). 
Color: pily yellow

IR- $v \mathrm{~cm}^{-1}$; $3360(\mathrm{O}-\mathrm{H}$ emerged with (N-H), $2960(\mathrm{C}-\mathrm{H}$ for $\left.\mathrm{CH}_{3}\right), 2925,2869\left(\mathrm{C}-\mathrm{H}\right.$ for $\left.\mathrm{CH}_{2}\right), 1640(\mathrm{C}=\mathrm{O}), 1610$, 1481 (aromatic skelton), $1016(\mathrm{C}-\mathrm{H})$ bending vibration of tetra substituted benzene.

\subsubsection{Polymer 4}

(Bis phenol-A, p-hydroxy benzoyl hydrazine dithioformic acid, formaldehyde).

Color: pily yellow

IR- $v \mathrm{~cm}^{-1}$; 3360 (O-H emerged with N-H), 2960 (C-H for $\left.\mathrm{CH}_{2}\right), 2900,2866\left(\mathrm{C}-\mathrm{H}\right.$ for $\left.\mathrm{CH}_{2}\right), 1614,1481$ (aromatic skelton), $1022(\mathrm{C}-\mathrm{H})$ bending vibration of tetra substituted benzene. $(\%)$ :

Combustion analysis (C, H, N and S) for $\mathrm{C}_{28} \mathrm{H}_{28} \mathrm{~N}_{2} \mathrm{O}_{4} \mathrm{~S}_{2}$

Calculated: $(\mathrm{C}=64.63, \mathrm{H}=5.38, \mathrm{~N}=5.38, \mathrm{~S}=12.30)$

Found: $(\mathrm{C}=64.98, \mathrm{H}=5.62, \mathrm{~N}=5.69, \mathrm{~S}=13.01)$.

\subsubsection{Polymer 5}

(Phenol, 2-(4-amino-5-mercapto-1,2,4-triazol-3 yl-) phenol, formaldehyde).

Color: dark brown

IR- $v \mathrm{~cm}^{-1}$; 3458 (O-H emerged with N-H), 2921, 2894 $\left(\mathrm{C}-\mathrm{H}\right.$ for $\left.\mathrm{CH}_{2}\right), 1620(\mathrm{C}=\mathrm{N}), 1475$ (aromatic skelton), 1018 (out of plan of C-H bending of tetra substituted benzene ring). $(\%)$ :

Combustion analysis (C, $\mathrm{H}, \mathrm{N}$ and $\mathrm{S}$ ) for $\mathrm{C}_{18} \mathrm{H}_{17} \mathrm{~N}_{4} \mathrm{O}_{2} \mathrm{~S}$

Calculated: $(\mathrm{C}=61.18, \mathrm{H}=4.81, \mathrm{~N}=15.86, \mathrm{~S}=9.06)$

Found: $(\mathrm{C}=60.01, \mathrm{H}=5.33, \mathrm{~N}=15.98, \mathrm{~S}=9.03)$.

\subsubsection{Polymer 6}

(Phenol, 4-(4-amino-5-mercapto-1,2,4-triazol-3 yl-) phenol, formaldehyde).

Color: pily yellow

IR- $v$ cm $^{-1}$; 3406 (O-H emerged with N-H), 3010 (C-H aromatic), 2920, $2883\left(\mathrm{C}-\mathrm{H}\right.$ for $\left.\mathrm{CH}_{2}\right),(\mathrm{C}=\mathrm{N}), 1606,1475$ (aromatic skelton), 1018 (out of plane of $\mathrm{C}-\mathrm{H}$ bending of tetra substituted benzene).

\subsubsection{Polymer 7}

(Bis phenol-A, 2-(4-amino-5-mercapto-1,2,4-triazol-3 ylphenol, formaldehyde).

Color: yellow

IR- $v \mathrm{~cm}^{-1} ; 3365$ (O-H emerged with N-H), 3049 (C-H aromatic), 2962, 2929 (C-H for $\left.\mathrm{CH}_{2}\right), 2869$ (C-H for $\left.\mathrm{CH}_{2}\right), 1606(\mathrm{C}=\mathrm{N}), 1606,1481$ (aromatic skelton), 1016 (out of plane bending of $\mathrm{C}-\mathrm{H}$ of tetra substituted benzene).

\subsubsection{Polymer 8}

(Bis phenol-A, 4-(4-amino-5-mercapto-1,2,4-triazol-3-yl) phenol, formaldehyde).
Color: yellow

IR- $v \mathrm{~cm}^{-1}$; $3402(\mathrm{O}-\mathrm{H}$ emerged with N-H), 3056 (C-H aromatic), $2962\left(\mathrm{C}-\mathrm{H}\right.$ for $\left.\mathrm{CH}_{2}\right), 2931,2875(\mathrm{C}-\mathrm{H}$ for $\left.\mathrm{CH}_{2}\right), 1600(\mathrm{C}=\mathrm{N}), 1600,1479$ (aromatic skelton), 1018 (out of plane bending of $\mathrm{C}-\mathrm{H}$ of tetra substituted benzene).

Combustion analysis (C, H, N and S) for $\mathrm{C}_{28} \mathrm{H}_{27} \mathrm{~N}_{4} \mathrm{O}_{3} \mathrm{~S}$ (\%):

Calculated: $(\mathrm{C}=67.33, \mathrm{H}=5.41, \mathrm{~N}=11.32, \mathrm{~S}=6.4)$

Found: $(\mathrm{C}=68.08, \mathrm{H}=5.52, \mathrm{~N}=11.99, \mathrm{~S}=6.52)$

\subsubsection{Polymer 9}

(Phenol, $o$-hydroxy benzoic acid thiosemicarbazide, formaldehyde).

Color: orange.

IR- $v \mathrm{~cm}^{-1} ; 3375$ (O-H emerged with N-H), 3099 (C-H aromatic), 2910, 2881 (C-H for $\left.\mathrm{CH}_{2}\right), 1600,1475$ (aromatic skelton), 1016 (out of plane bending of $\mathrm{C}-\mathrm{H}$ of tetra substituted benzene).

Combustion analysis (C, H, N and S) for $\mathrm{C}_{18} \mathrm{H}_{18} \mathrm{~N}_{3} \mathrm{O}_{3} \mathrm{~S}$ (\%):

Calculated: $(\mathrm{C}=60.67, \mathrm{H}=5.05, \mathrm{~N}=11.79, \mathrm{~S}=8.98)$

Found: $(\mathrm{C}=60.32, \mathrm{H}=5.11, \mathrm{~N}=11.39, \mathrm{~S}=9.09)$.

\subsubsection{Polymer 10}

(Phenol, $p$-hydroxy benzoic acid thiosemicarbazide, formaldehyde).

Color: orange

IR- $v \mathrm{~cm}^{-1}$; 3406 (O-H emerged with N-H), 3097 (C-H aromatic), 2920, $2883\left(\mathrm{C}-\mathrm{H}\right.$ for $\left.\mathrm{CH}_{2}\right), 1610,1475$ (aromatic skelton), $1211(\mathrm{C}=\mathrm{S}), 1018$ (out of plane bending of $\mathrm{C}-\mathrm{H}$ of tetra substituted benzene).

\subsubsection{Polymer 11}

(Bis phenol-A, o-hydroxyl benzoic acid thiosemicarbazide, formaldehyde).

Color: milky

IR- $v \mathrm{~cm}^{-1}$; 3404 (O-H emerged with N-H), 3041 (C-H aromatic), $2950\left(\mathrm{C}-\mathrm{H}\right.$ for $\left.\mathrm{CH}_{2}\right), 2929,2873$, $(\mathrm{C}-\mathrm{H}$ for $\left.\mathrm{CH}_{2}\right), 1670(\mathrm{C}=\mathrm{O}), 1610,1481$ (aromatic skelton), 1215 $(\mathrm{C}=\mathrm{S}), 1016$ (out of plane bending of $(\mathrm{C}-\mathrm{H})$ of tetra substituted benzene).

\subsubsection{Polymer 12}

(Bis phenol-A, $p$-hydroxy benzoic acid thiosemicarbazide, formaldehyde).

Color: milky

IR- $v \mathrm{~cm}^{-1}$; 3390 (O-H emerged with N-H), 3090 (C-H aromatic), $2945\left(\mathrm{C}-\mathrm{H}\right.$ for $\left.\mathrm{CH}_{2}\right), 2930,2870(\mathrm{C}-\mathrm{H}$ for $\left.\mathrm{CH}_{2}\right), 1675(\mathrm{C}=\mathrm{O}), 1625,1486$ (aromatic Skelton), 1222 $(\mathrm{C}=\mathrm{S}$ ), 1020 (out of plane bending of $\mathrm{C}-\mathrm{H}$ of tetra substituted benzene).

Combustion analysis $(\mathrm{C}, \mathrm{H}, \mathrm{N}$ and $\mathrm{S})$ for $\mathrm{C}_{28} \mathrm{H}_{29} \mathrm{~N}_{3} \mathrm{O}_{4} \mathrm{~S}$ $(\%)$ : 
Calculated: $(\mathrm{C}=66.79, \mathrm{H}=5.76, \mathrm{~N}=8.34, \mathrm{~S}=6.36)$

Found: $(\mathrm{C}=67.09, \mathrm{H}=5.66, \mathrm{~N}=8.92, \mathrm{~S}=6.52)$.

\section{Results and Discussion}

\subsection{Spectral Characterization of Organic Monomers and Co-Polymers}

The synthesis of potassium (ortho or para) hydroxy benzoyl hydrazine dithioformate $\left[\mathrm{M}_{1}\right.$ and $\left.\mathrm{M}_{2}\right]$ were achieved by the reaction of (ortho/para) hydroxy benzoyl hydrazine with carbon disulfide in ethanolic potassium hydroxide, the IR-spectra of these two compounds exhibited a sharp band at $(1641,1650) \mathrm{cm}^{-1}$ which was clearly attributable to $v(\mathrm{C}=\mathrm{O})$, the lower value of ortho-derivative due to the chelated of $(\mathrm{O}-\mathrm{H})$ group with $(\mathrm{C}=\mathrm{O})$ through hydrogen bonding, the spectra also showed a medium band in the $(1335,1331) \mathrm{cm}^{-1}$ due to $v(\mathrm{C}=\mathrm{S})$, moreover, these two compounds exhibited significant bands in the region $(739,856) \mathrm{cm}^{-1}$ that clearly indicated the presence of ortho and para substituted benzene. Finally, the spectra of $\mathrm{M}_{1}$ and $\mathrm{M}_{2}$ displayed bands in (3261, $3382 \mathrm{~cm}^{-1}$ attributable to the free $(\mathrm{N}-\mathrm{H})$ group, these two value were overlapped $\mathrm{cm}^{-1}$ with the value of $(\mathrm{O}-\mathrm{H})$ group and broad band's with multiple peaks in the region (3074 and 3153) $\mathrm{cm}^{-1}$ assignable to the intra molecularly hydrogen bonded $\mathrm{N}-\mathrm{H}$ group. The $\mathrm{H}^{1}$-NMR Spectra of these salts $\left[\mathrm{M}_{1}\right.$ and $\left.\mathrm{M}_{2}\right]$ show a singlet signal in the region (2.5) ppm for one proton of (NH-CS) group and a singlet signal at $(7.9,7.7) \mathrm{ppm}$ for one proton of the (NH-CO) group due to the higher electron withdrawing of the- $(\mathrm{C}=\mathrm{O})$ group than $-(\mathrm{C}=\mathrm{S})$ group. The aromatic protons of the ortho disubstituted phenol $\left[\mathrm{M}_{1}\right]$ appeared as multiple in the regine $(6.9-7.9) \mathrm{ppm}$, the proton on the 3-position give in the region (6.9) ppm, on the 4-position give in the region (7.3) ppm, the 5-position give in the region (7.0) ppm, where the 6-position (7.9) ppm while aromatic protons of para disubstituted phenol $\left[\mathrm{M}_{2}\right]$ gives two kinds of chemical shift due to the symmetry in the region $(6.8-7.7) \mathrm{ppm}$. The protons on the 2-position gives in the region (7.7) for $\mathrm{H}_{2}$ and $\mathrm{H}_{6}$, where the protons $\mathrm{H}_{3}$ and $\mathrm{H}_{5}$ at position (3) and (5) gives signal as doublet at 6.8. These two salts $\left[\mathrm{M}_{1}\right.$ and $\left.\mathrm{M}_{2}\right]$ were cyclized with excess of hydrazine hydrate to the corresponding 1,2,4triazoles $\left[\mathrm{M}_{3}\right.$ and $\left.\mathrm{M}_{4}\right]$. The presence of a medium to high intensity band in the $(1615,1612) \mathrm{cm}^{-1}$ region attributeable to $v(\mathrm{C}=\mathrm{N})$ are good evidence for successful cyclization.

The presence of two strong bands around $1300 \mathrm{~cm}^{-1}$ showed that $\left[\mathrm{M}_{3}\right.$ and $\left.\mathrm{M}_{4}\right]$ exists predominately in the thione from a very weak band at $(2761,2590) \mathrm{cm}^{-1}$, however indicated the presence of thiol form in the tautomeric mixture. The band due to $v(\mathrm{~N}-\mathrm{H})$ associated with the thion form appears in the $(3294-3190) \mathrm{cm}^{-1}$ and $(3280-3079) \mathrm{cm}^{-1}$ regions.
The $\mathrm{H}^{1}-\mathrm{NMR}$ spectra of the triazoles $\left[\mathrm{M}_{3}\right.$ and $\left.\mathrm{M}_{4}\right]$ was in accord with assigned structures and there is shown the $(\mathrm{N}-\mathrm{H})$ and $(\mathrm{S}-\mathrm{H})$ tautomeric protons in the region $(2.5-$ 3.5) $\mathrm{ppm}$ and aromatic protons in the region (6.7 - 7.8) ppm, (ortho or para) hydroxy benzoyl hydrazine, which were further reacted with potassium thiocyanate in the presence of hydrochloric acid to obtain $o$-hydroxy benzoic acid thiosemicarbzide $\left[\mathrm{M}_{5}\right]$ and para hydroxy benzoic acid thiosemicarbzide $\left[\mathrm{M}_{6}\right]$ respectively. The IRspectra of the $\mathrm{M}_{5}$ and $\mathrm{M}_{6}$ exhibited characteristic absorption bands due to $\mathrm{NH} \cdot \mathrm{NH}_{2},(\mathrm{C}=\mathrm{O})$ and $(\mathrm{C}=\mathrm{S})$ at $(3438$, $3388,3386$ and 3328$) \mathrm{cm}^{-1},(1650,1643) \mathrm{cm}^{-1}$ and $(1352$, 1386) $\mathrm{cm}^{-1}$. A series of cross-linking terpolymers $\left(\mathrm{P}_{1}\right.$ $\mathrm{P}_{12}$ ) [phenol- $\mathrm{M}_{\mathrm{n}}$-formaldehyde] and [Bis phenol-A- $\mathrm{M}_{\mathrm{n}}$ formaldehyde] where $M_{n}=$ monomer $\left(M_{1}-M_{6}\right)$ have been synthesized via electrophilic aromatic substitution. The synthetic routes are illustrated in Scheme 1. The use of phenol as a co-monomer allows for preparing crosslink polymers, since the phenol ring has three activated positions for formaldehyde to substitution, phenol has three reactive sites (i.e. both ortho and para positions), while using Bis phenol-A has four activated positions for formaldehyde to substitution (four ortho position), therefore branching in polymers $\left(\mathrm{P}_{1}-\mathrm{P}_{12}\right)$ is inevitable as higher molecular weight develops. The IR-spectra of the terpolymers $\left[\mathrm{P}_{1}-\mathrm{P}_{12}\right]$ support the structural assignments for the polymers and are in agreement with spectral data obtained for the model compounds shown in Scheme 1. IR-spectra for all the co polymers showed the absorption band for $\mathrm{O}-\mathrm{H}$ stretching around $(3300) \mathrm{cm}^{-1}$ this absorption being overlapped with the value of $(\mathrm{N}-\mathrm{H})$. The absorption bands at $1018 \mathrm{~cm}^{-1}$ belong to out of the plane vibration of hydrogen in the tetra substituted aromatic ring. In addition other characteristic absorption bands, which were discussed previously due to specific groups present in the various polymers, were also evident in the IR spectra. The micro analysis of co polymers $\left(\mathrm{P}_{1}, \mathrm{P}_{4}, \mathrm{P}_{5}\right.$, $\mathrm{P}_{8}, \mathrm{P}_{9}$ and $\mathrm{P}_{12}$ ) reflected the characteristic repeating unit of each polymer. The analysis shows that the nitrogen is present within the co-polymers which give a good evidence of the incorporation of the chelating group in the backbone of the polymeric matrix. All the spectral charts for monomers and polymers are shown in Figures 1-12.

\subsection{Thermal Analysis}

The thermal behavior of the co-polymers $\left(\mathrm{P}_{1}, \mathrm{P}_{3}\right.$ and $\left.\mathrm{P}_{4}\right)$ were evaluated by TGA in air at a heating rate of $10^{\circ} \mathrm{C} / \mathrm{min}$. The thermograms of these co-polymers are given in Figures 13-15. Table 1 gives the thermal parameters that can be deduced from the TGA curve. All the phenolic co-polymers showed a high thermal stability with regard to their first major decomposition stage this can be related to two factors, firstly all the chelating 


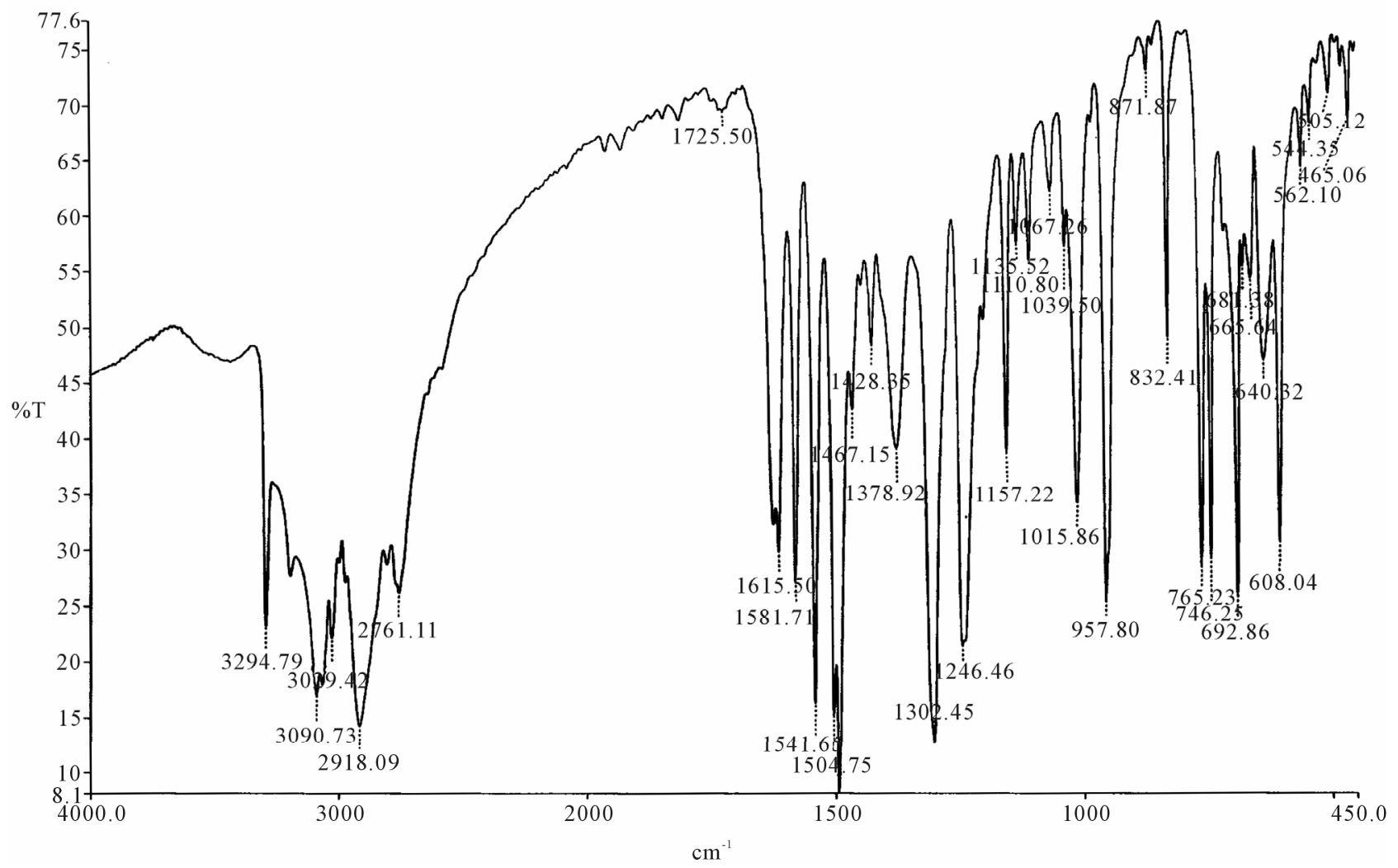

Figure 1. IR spectrum of $M_{3}$.

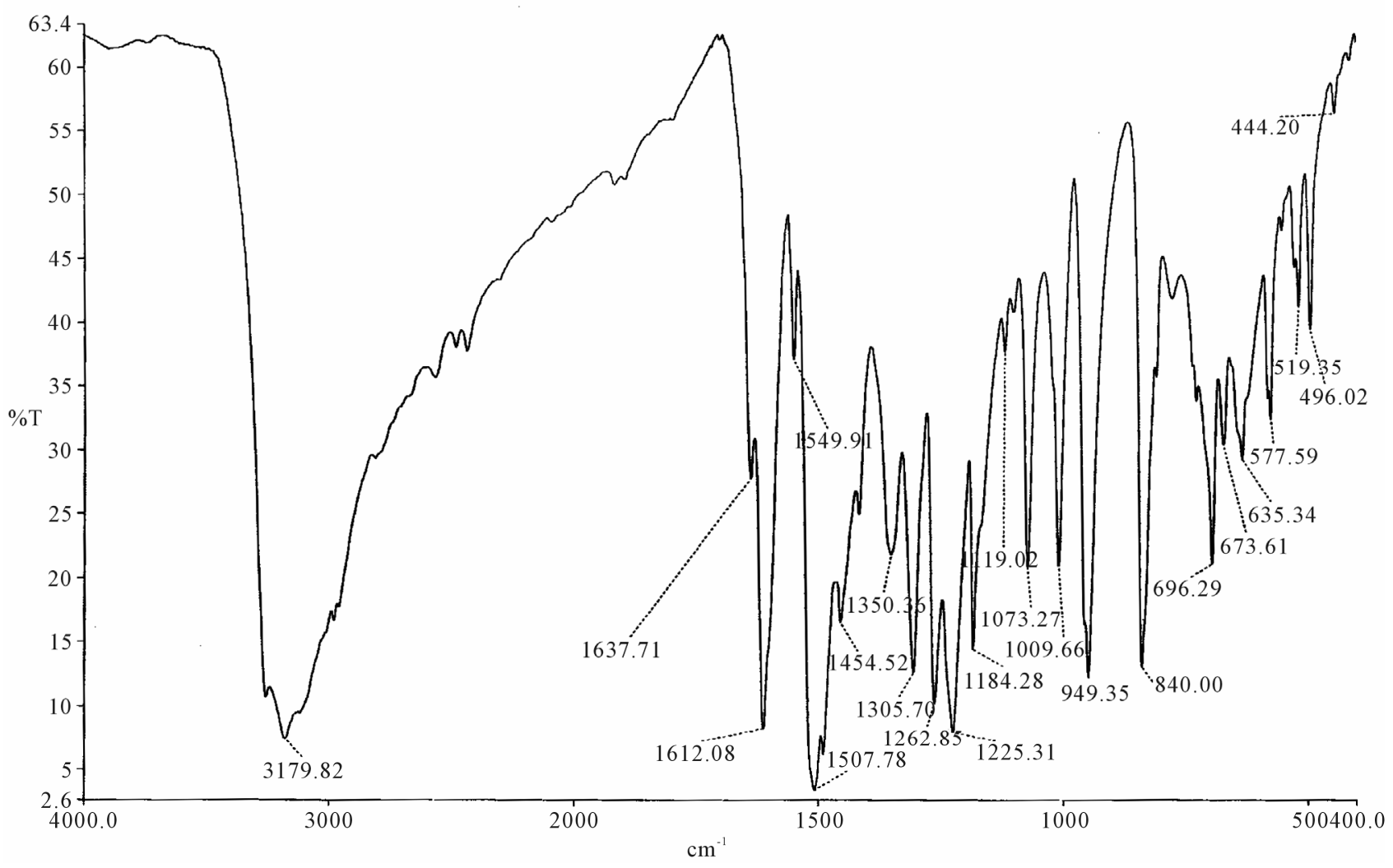

Figure 2. IR spectrum of $M_{4}$. 


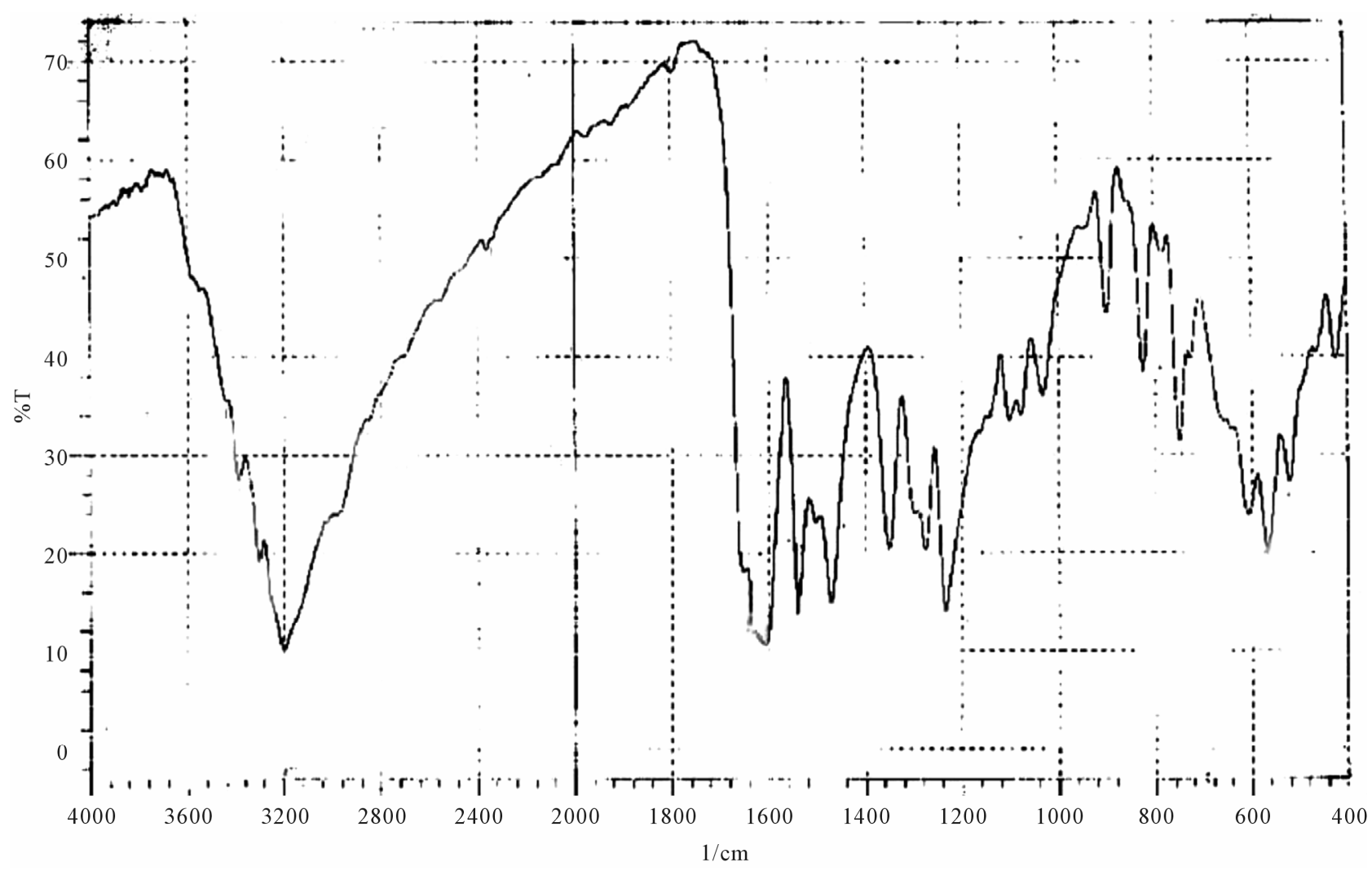

Figure 3. IR spectrum of $M_{5}$.

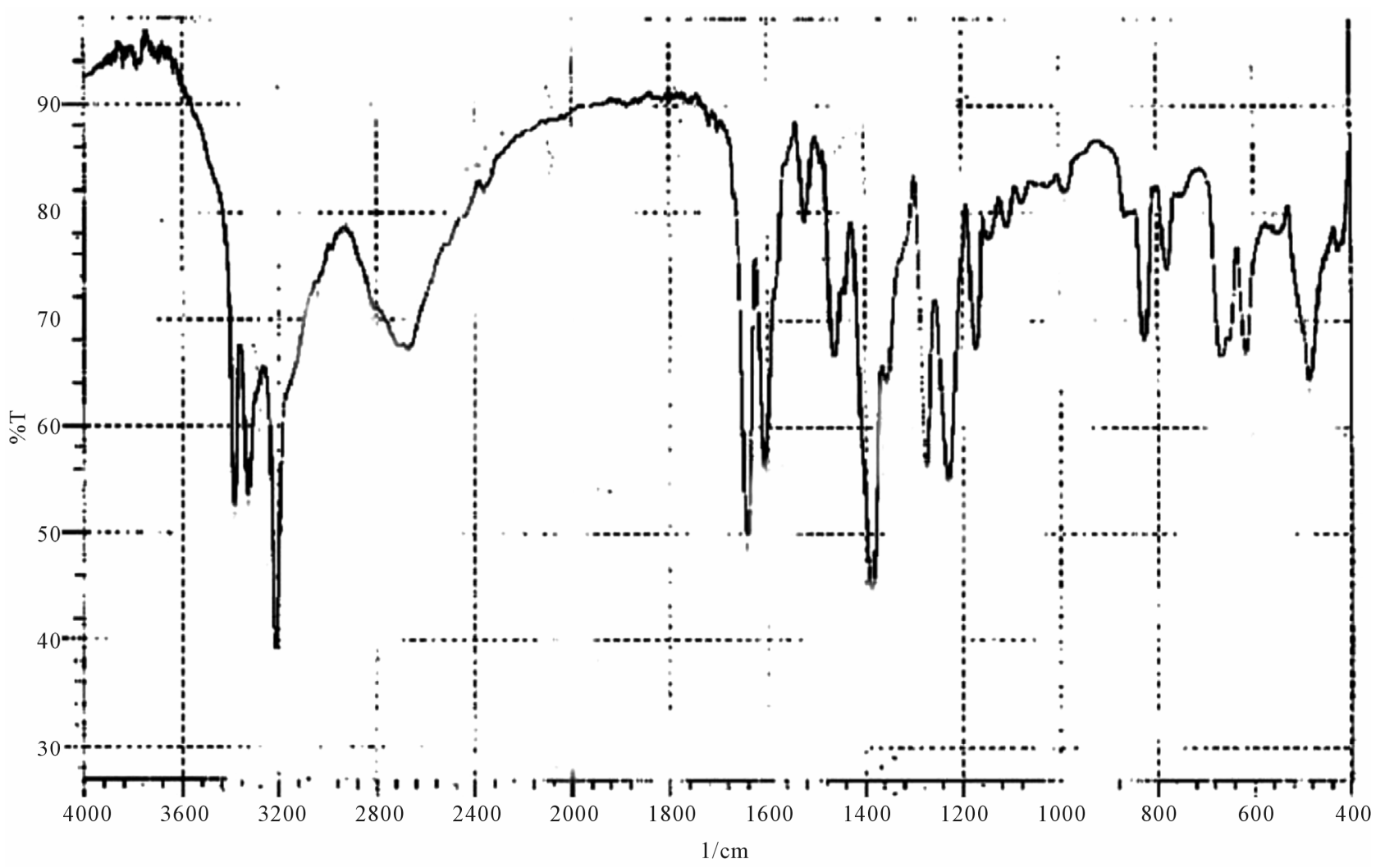

Figure 4. IR spectrum of $M_{6}$. 


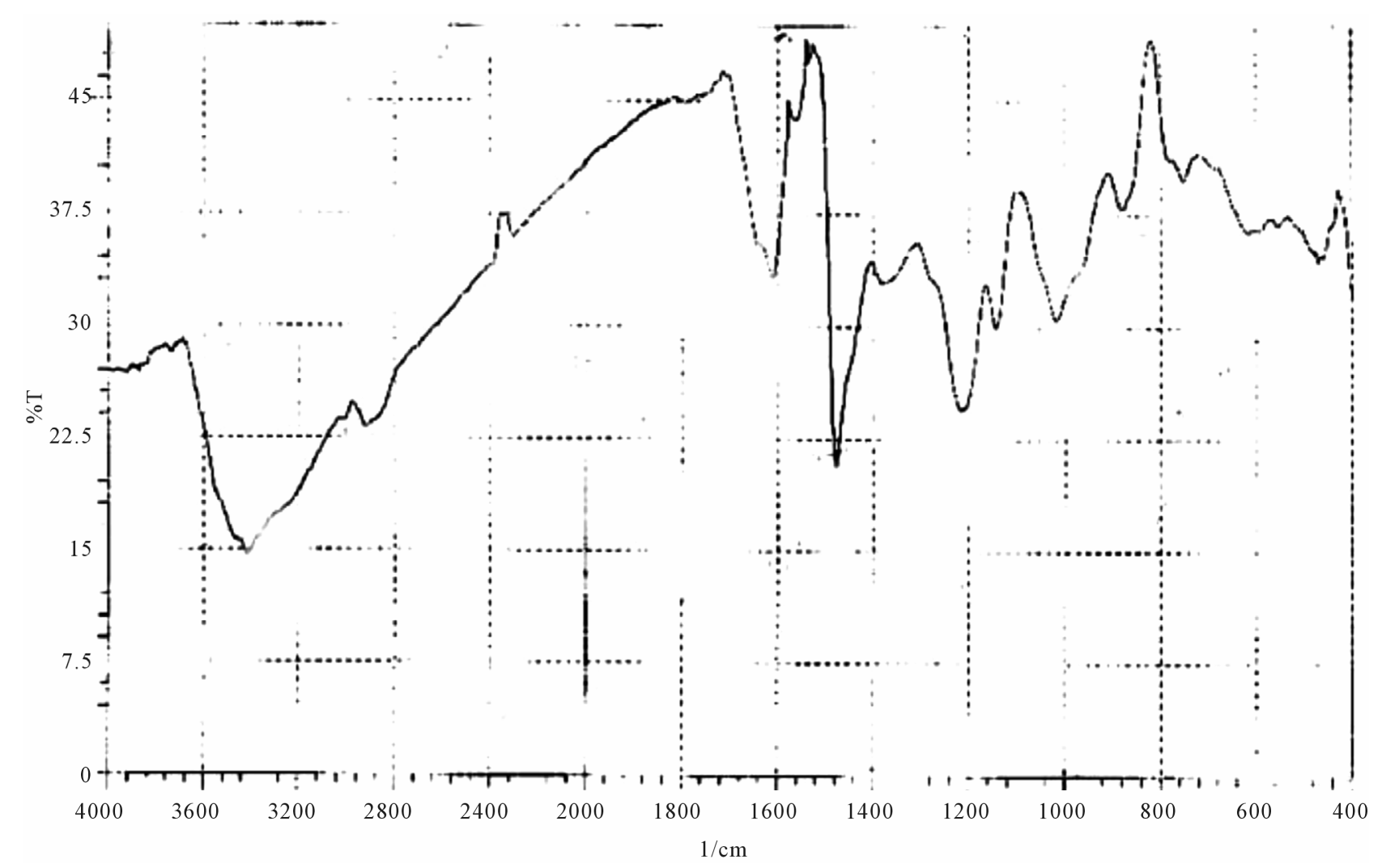

Figure 5. IR spectrum of $\mathbf{P}_{1}$.

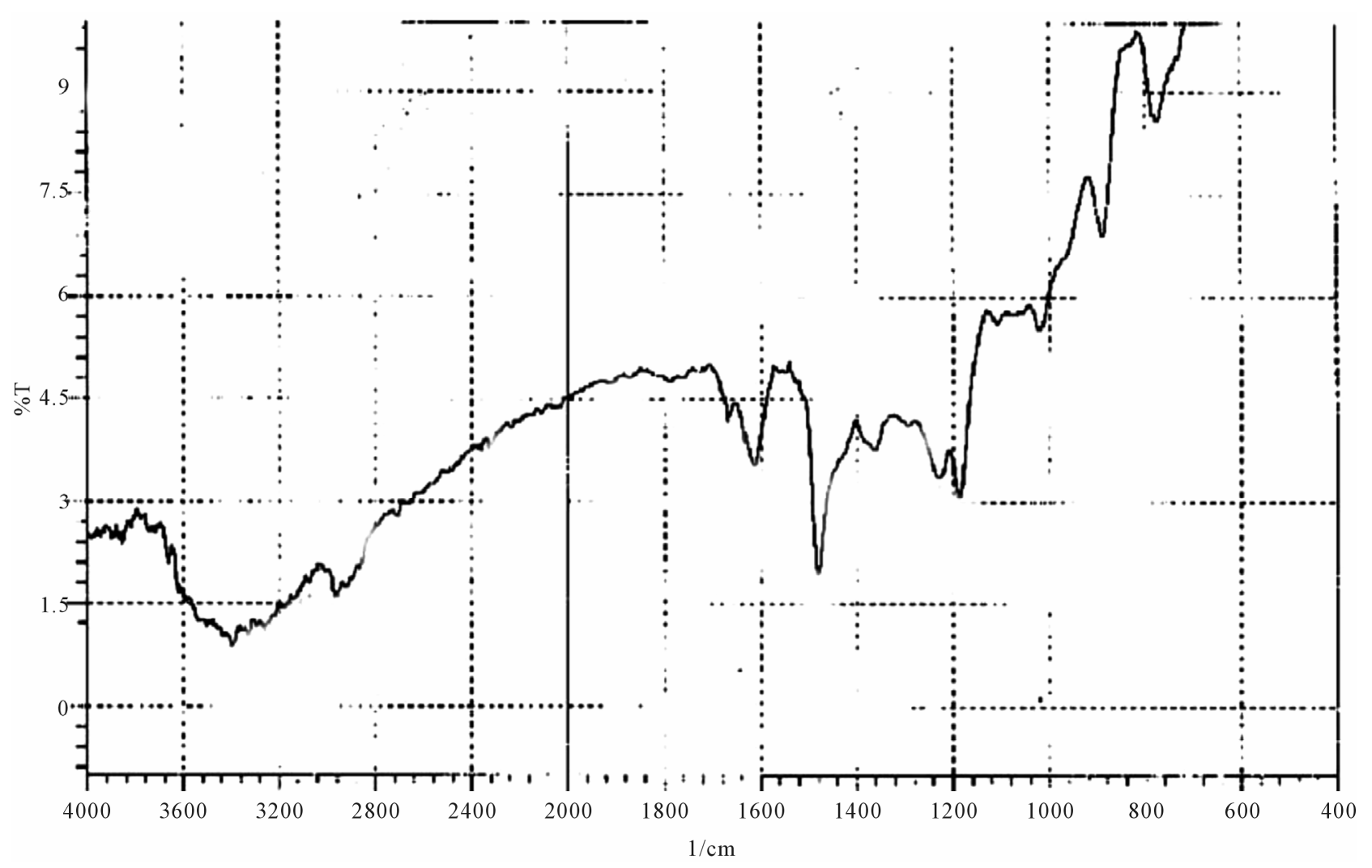

Figure 6. IR spectrum of $\mathbf{P}_{4}$. 


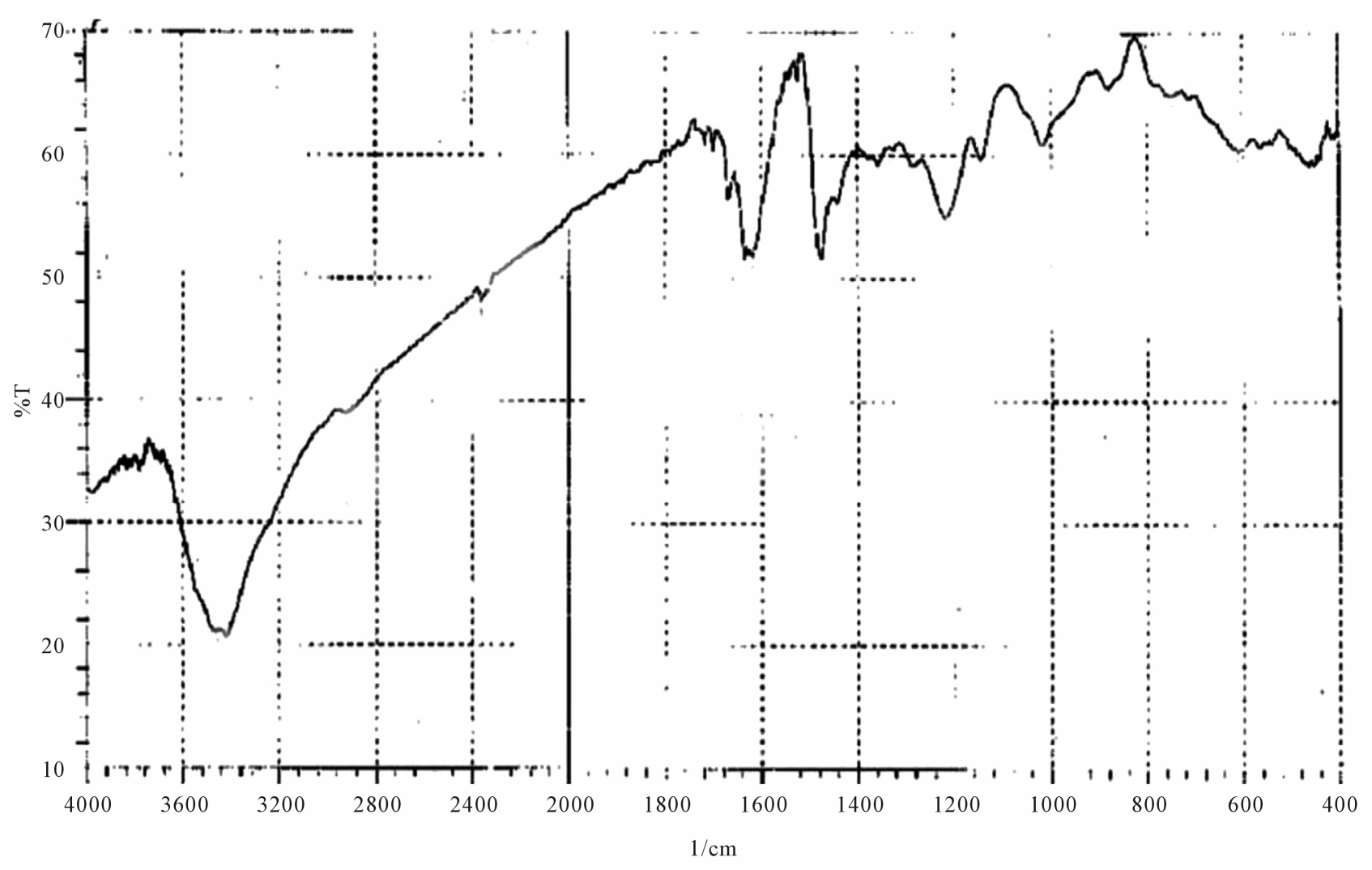

Figure 7. IR spectrum of $\mathbf{P}_{5}$.

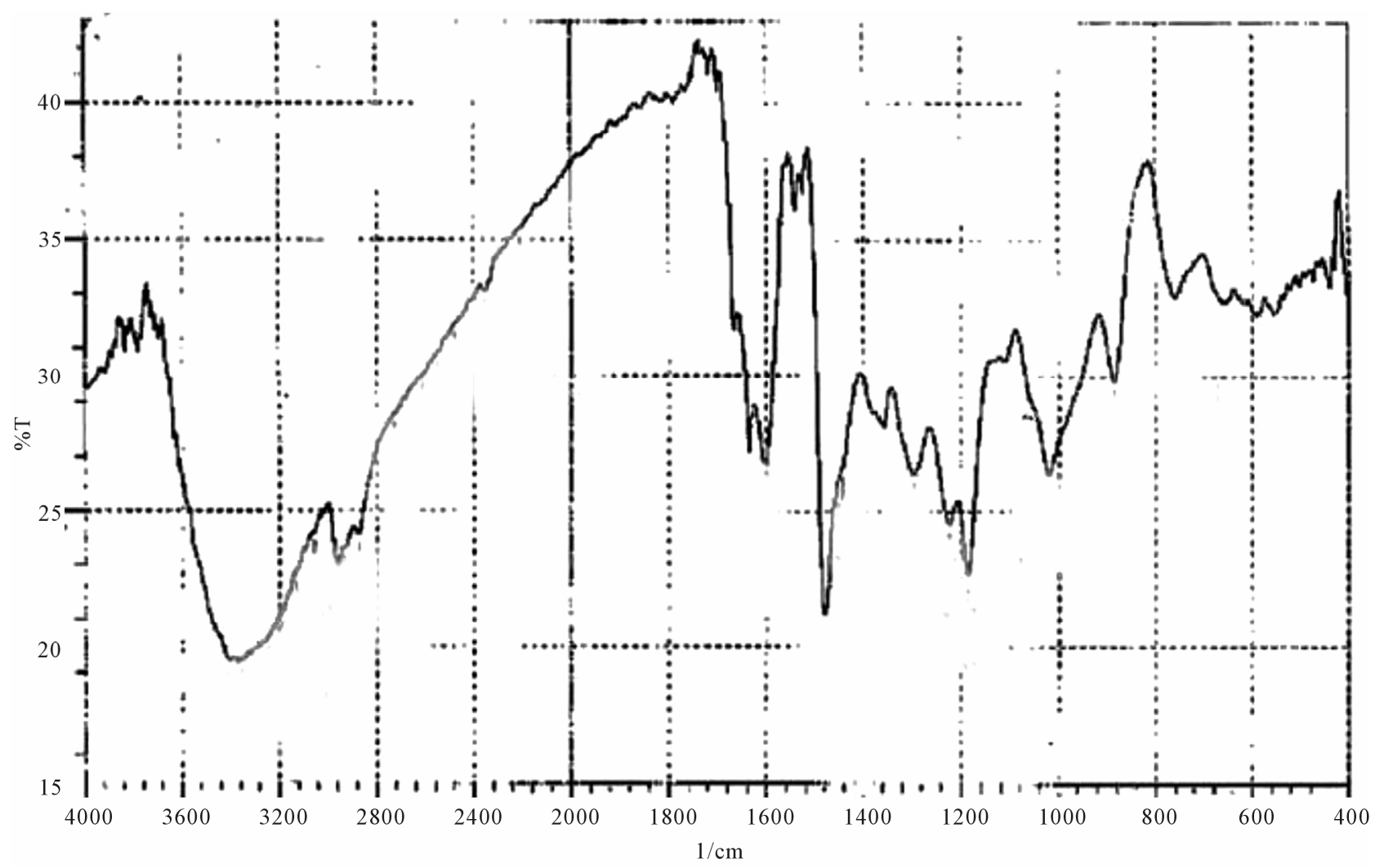

Figure 8. IR spectrum of $\mathbf{P}_{8}$. 


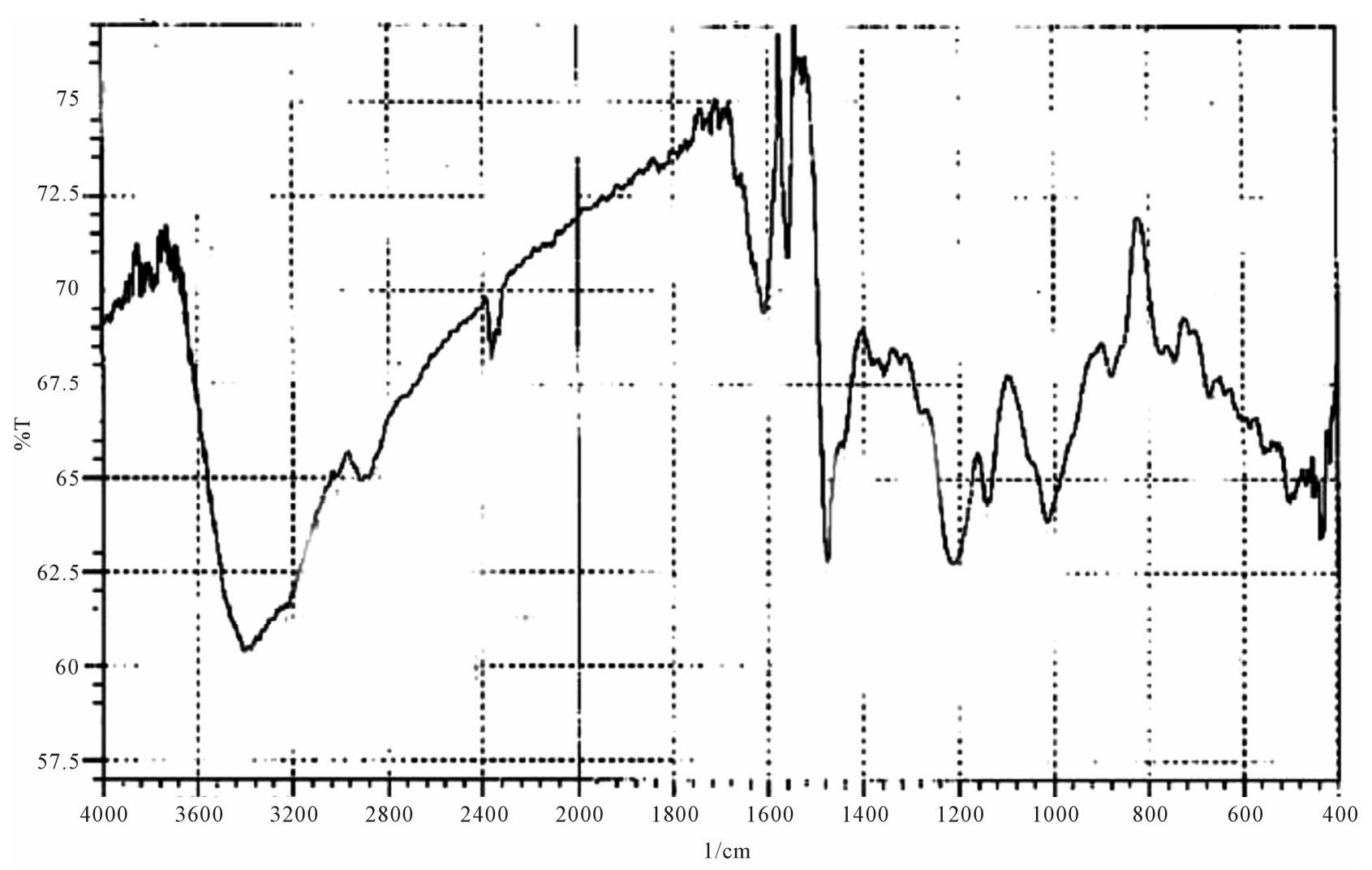

Figure 9. IR spectrum of $\mathbf{P}_{\mathbf{9}}$.

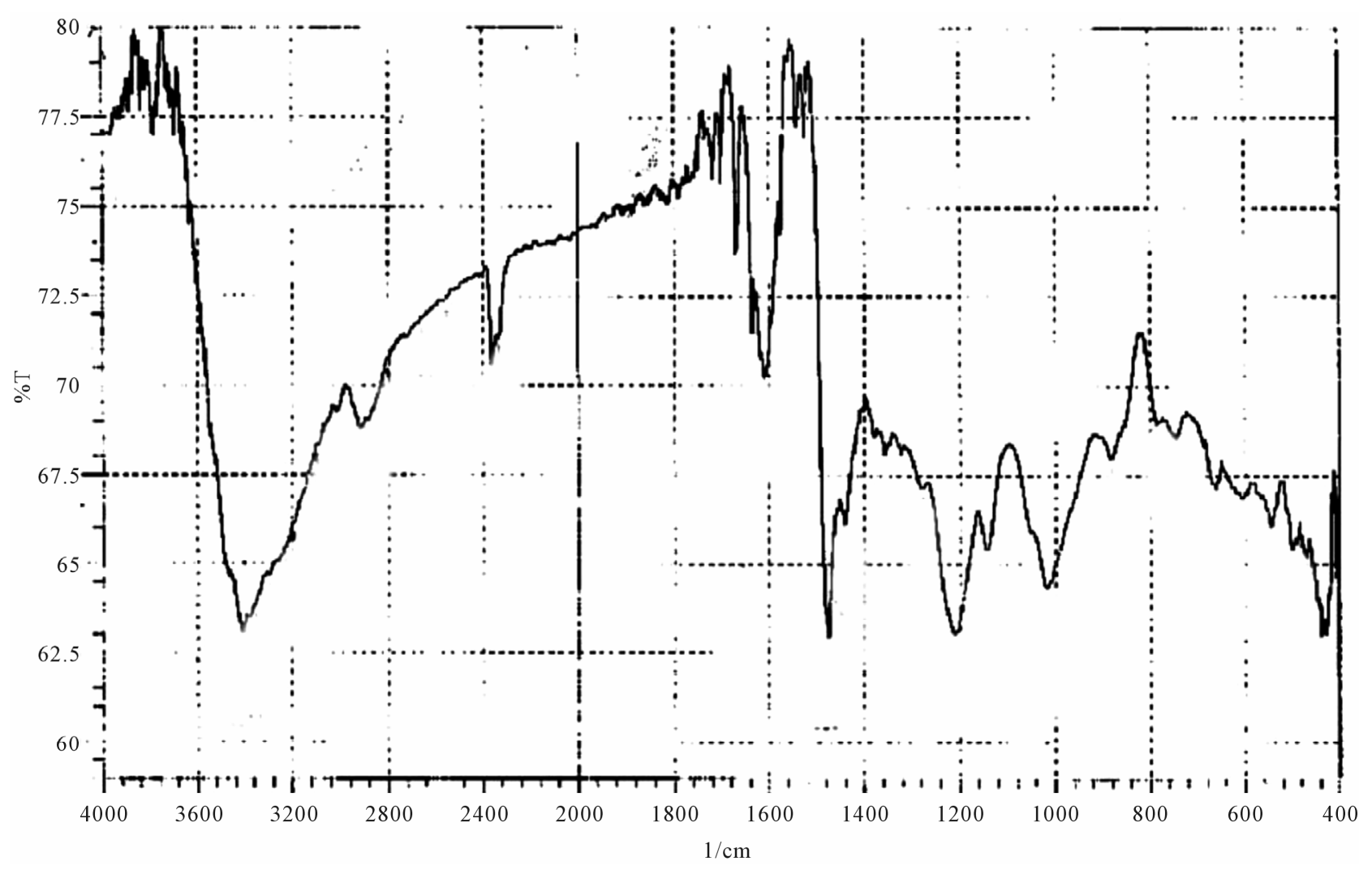

Figure 10. IR spectrum of $P_{10}$. 

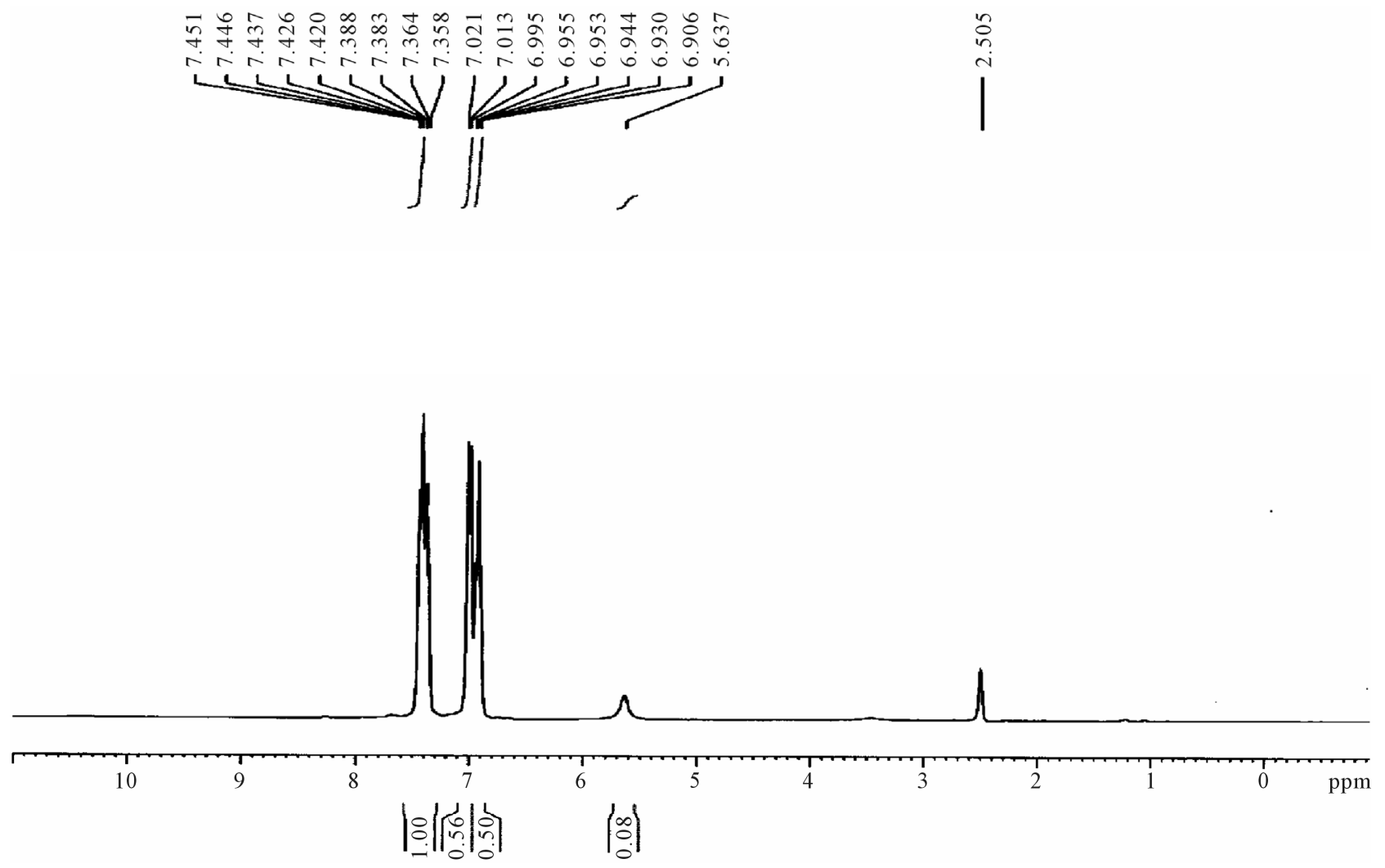

Figure 11. $\mathrm{H}^{1}$-NMR spectra of $\mathrm{M}_{3}$.
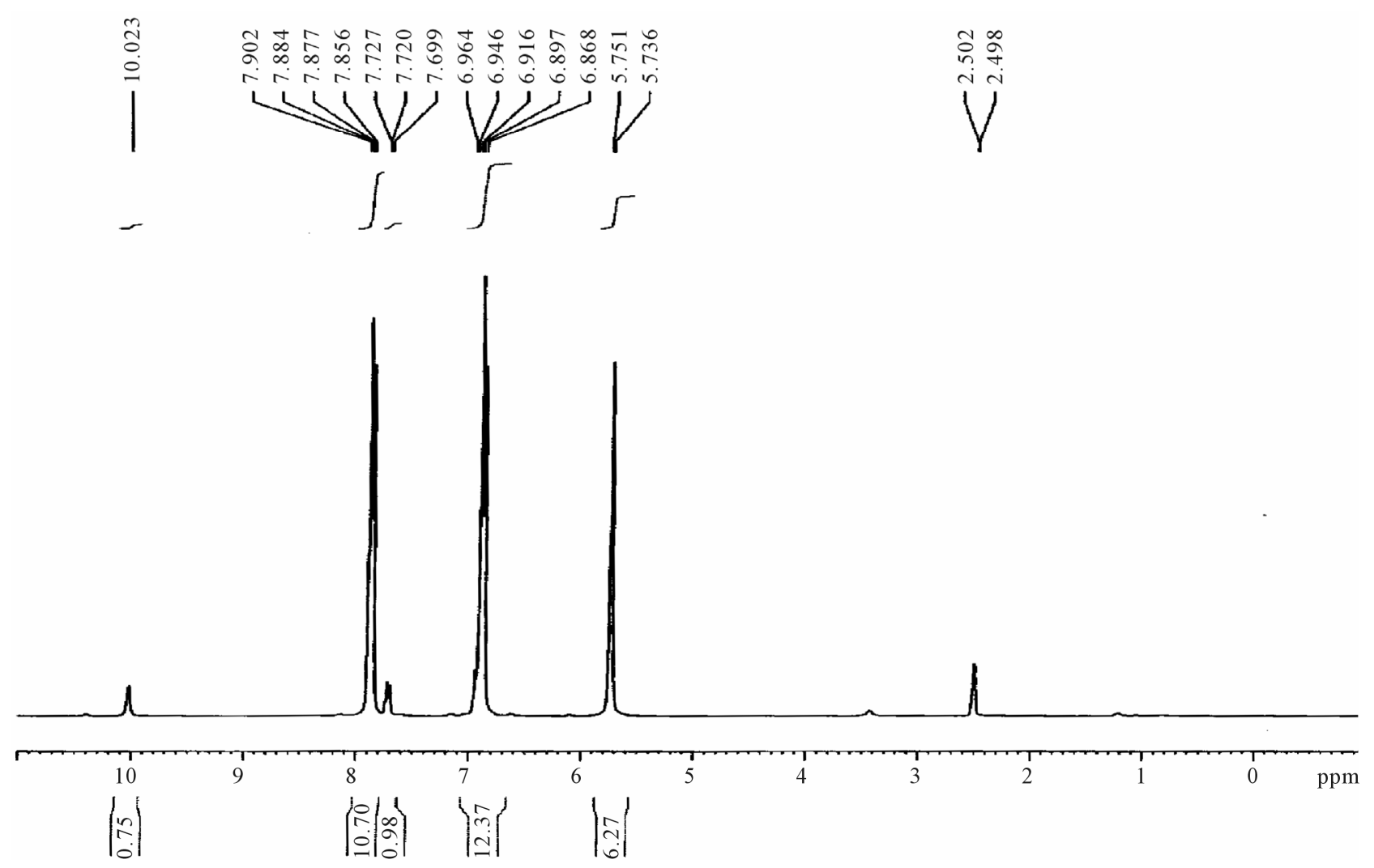

Figure 12. $\mathrm{H}^{1}$-NMR spectrum of $\mathrm{M}_{4}$. 
Table 1. Some thermal stability characters determined from TGA thermogram of polymers $\left(\mathbf{P}_{1}, \mathbf{P}_{3}\right.$ and $\left.\mathbf{P}_{4}\right)$.

\begin{tabular}{cccccc}
\hline Polymer No. & $\operatorname{Idt}^{\circ} \mathrm{C}$ & Temp. of $(50 \%)$ weight loss, ${ }^{\circ} \mathrm{C}$ & Ts $^{*}{ }^{\circ} \mathrm{C}$ & Char cont $\%$ & Temp ${ }^{\circ} \mathrm{C}$ \\
\hline $\mathrm{P}_{1}$ & 160 & $>800$ & 480 & 53.2 & 786 \\
$\mathrm{P}_{3}$ & 170 & 618 & 450 & 43.1 & 790 \\
$\mathrm{P}_{3}$ & 160 & 620 & 453 & 43.7 & 789 \\
\hline
\end{tabular}

${ }^{*}$ Ts: half volatilization temperature it can represent the temperature at which the polymer sample has half of its stable weight.

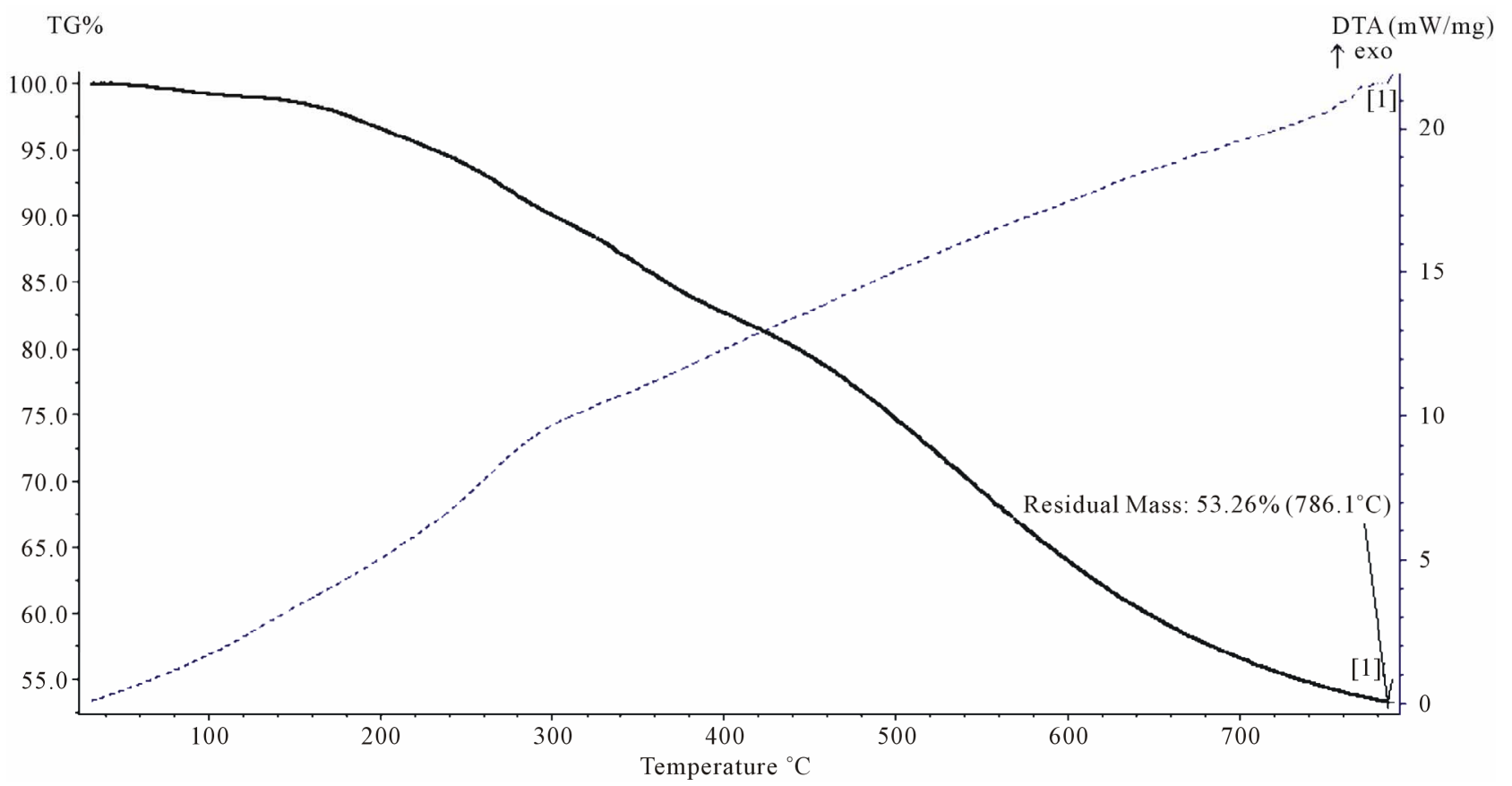

Figure 13. TGA thermogram of $P_{1}$.

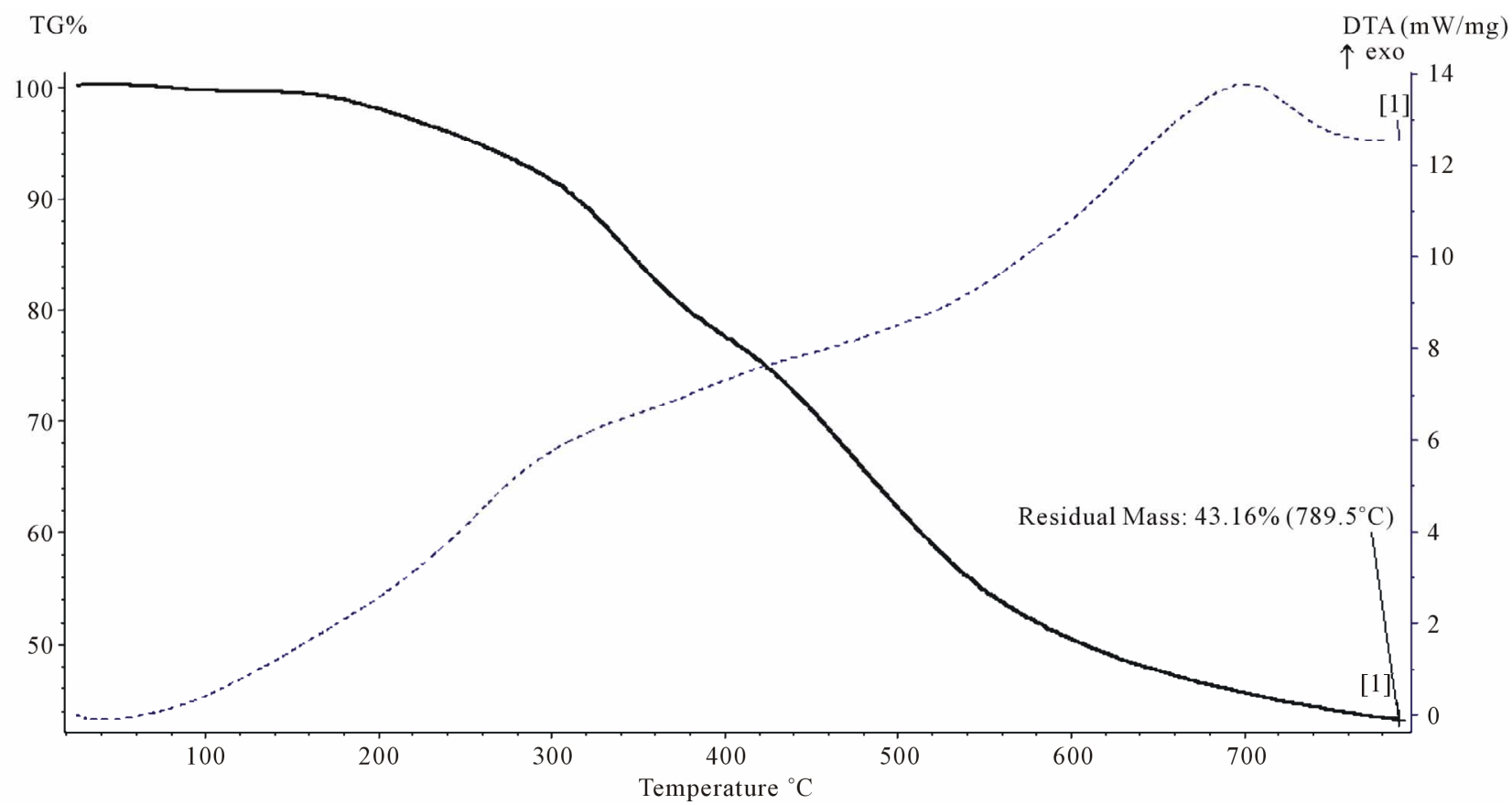

Figure 14. TGA thermogram of $P_{3}$. 


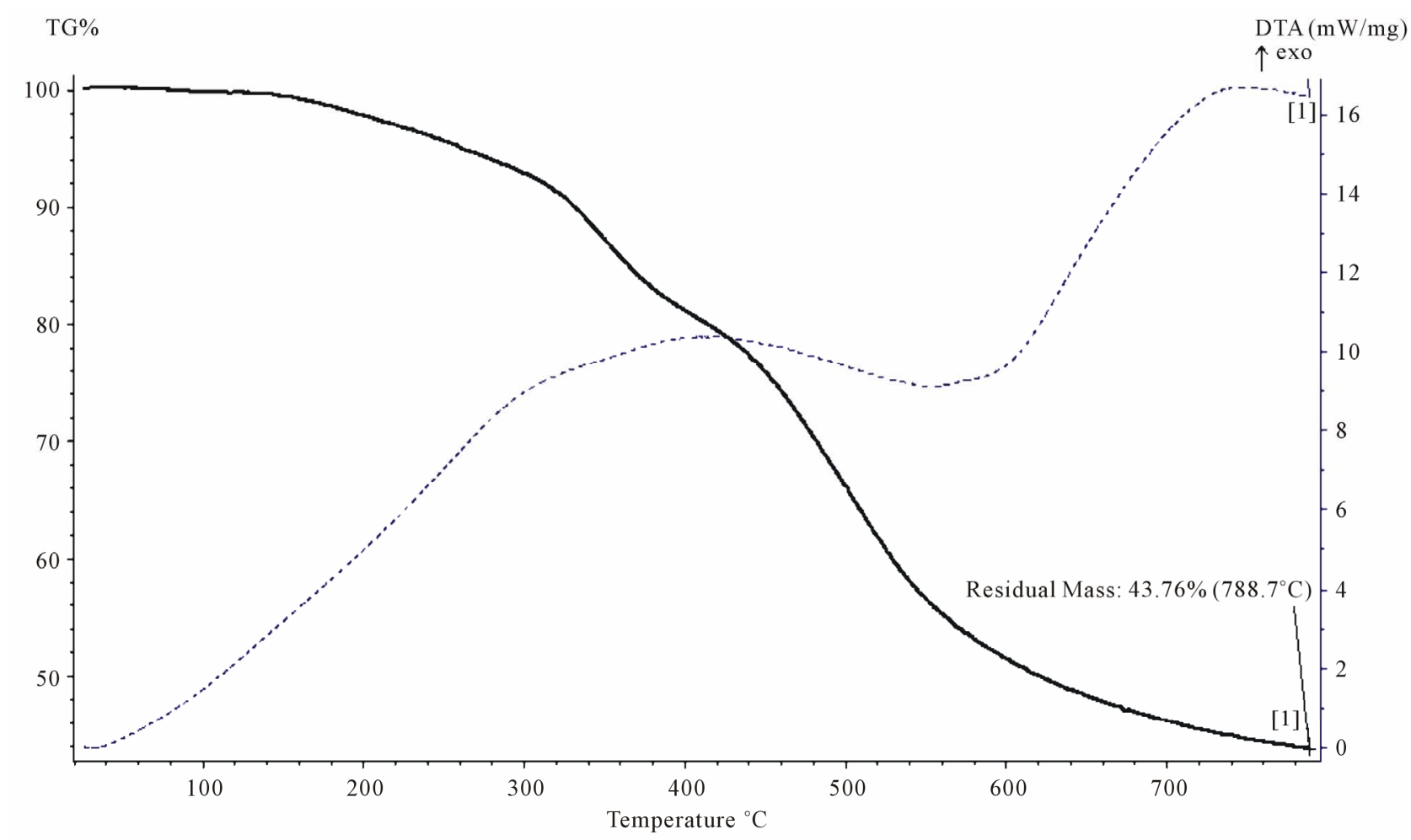

Figure 15. TGA thermogram of $\mathbf{P}_{4}$.

polymers are cross-linked due to their structures as they all contain $(50 \%)$ phenol, or bisphenol-A which are capable of the formation of three dimensional network. Secondly all the chelating polymers contains different heteroatom namely nitrogen, oxygen and sulfur in their structures which is a well known reason for the high thermal stability [14]. In all Figures 13-15 TGA curves show a small weigh loss in the range $(2-5) \%$ starting at $(160-170)^{\circ} \mathrm{C}$, which indicated to loss of observed moisture and entrapped solvent, dehydration also occurres in this range of temperature, which indicates the loss of $\mathrm{H}_{2} \mathrm{O}$ and formation of ether linkage.

Finally, the loss of formaline from any remaining hydroxyl methyl group leads to the formation of ether linkage $\left(\mathrm{CH}_{2}-\mathrm{O}-\mathrm{CH}_{2}\right)$. The second step decomposition which begins at $300^{\circ} \mathrm{C}$ and extent up to $600^{\circ} \mathrm{C}$ is most probably be due to random cleavage of polymeric resin affording simpler degradation products. Polymer $\left(\mathrm{P}_{1}\right)$ showed higher char content $53.26 \%$ compared with $\left(\mathrm{P}_{3}\right.$ and $\left.\mathrm{P}_{4}\right)$, which indicated that $\left(\mathrm{P}_{1}\right)$, has higher thermal stability than $\left(\mathrm{P}_{3}\right.$ and $\left.\mathrm{P}_{4}\right)$, polymer $\left(\mathrm{P}_{1}\right)$ which contain phenol as a co-monomer while polymers $\left(\mathrm{P}_{3}\right.$ and $\left.\mathrm{P}_{4}\right)$ contain a bisphenol-A as co-monomer. Minimum \% oxygen in the molecular formula of the repeating unit giving the highest thermal stability with a remarkable char content, this could be attributed to the fact that char content and thermal stability is reduced by increasing oxygen content in the polymers [15]. Figures $\mathbf{1 4}$ and $\mathbf{1 5}$ are very similar due to a very close structure of the two polymers.

\subsection{Analytical Evaluation of the Resins $\left(P_{1}-P_{12}\right)$}

Chelating resins are evaluated analytically by determining their selectivity for metal ions $\left(\mathrm{Cr}^{3+}, \mathrm{Co}^{2+}, \mathrm{Cu}^{2+}, \mathrm{Cd}^{2+}\right.$ and $\left.\mathrm{Pb}^{2+}\right)$. The chelating efficiency of resins $\left(\mathrm{P}_{1}-\mathrm{P}_{12}\right)$ was evaluated by determining the loading capacity of the studied resins for each metal ion under investigation. The loading capacity is represented by the amont of metal ion chelated or adsorbed by the resin in ( $\mathrm{mg}$ ion $/ \mathrm{g}$ resin). Table 2 shows that all the polymer $\left(\mathrm{P}_{1}-\mathrm{P}_{12}\right)$ gave high adsorption capacity for $\mathrm{Cr}^{3+}$ than that for $\left(\mathrm{Co}^{2+}, \mathrm{Cu}^{2+}\right.$, $\left.\mathrm{Cd}^{2+}, \mathrm{Pb}^{2+}\right)$. The results are in according with characteristic hetero atoms $(\mathrm{N}$ and $\mathrm{O})$ of the functional groups which easily binds to the hard metal ion $\left(\mathrm{Cr}^{3+}\right)$.

\section{Conclusion}

Twelve co-polymers containing dithioformic acid, thiosemicarbazide or 1,2,4-triazoles groups have been synthesized successfully by simple aromatic substitution reaction in basic medium. The refluxing time for the reaction of $\boldsymbol{o}$-isomers are less than $\boldsymbol{p}$-isomers while the yield of all $\boldsymbol{o}$-isomers are higher than $\boldsymbol{p}$-isomers for all reaction steps in Scheme 1. These observations can be explained by intra and inter molecular hydrogen bonding. The thermal stability of these co-polymers was found to depend on the chemical structures and to decrease with 
Table 2. Maximum loading capacity at $24 \mathrm{hr}$ shaking time of polymers $\left(\mathbf{P}_{1}-\mathbf{P}_{12}\right)$ toward different ions (mg ion/g resin).

\begin{tabular}{|c|c|c|c|c|c|c|c|c|c|c|c|c|}
\hline \multirow{2}{*}{ Ions } & \multicolumn{12}{|c|}{ Maximum loading capacity of polymers (mg ion/g resin) } \\
\hline & $\mathrm{P}_{1}$ & $\mathrm{P}_{2}$ & $\mathrm{P}_{3}$ & $\mathrm{P}_{4}$ & $\mathrm{P}_{5}$ & $\mathrm{P}_{6}$ & $\mathrm{P}_{7}$ & $\mathrm{P}_{8}$ & $\mathrm{P}_{9}$ & $\mathrm{P}_{10}$ & $\mathrm{P}_{11}$ & $\mathrm{P}_{12}$ \\
\hline $\mathrm{Cr}^{3+}$ & 8.9 & 9.7 & 9.9 & 10.0 & 10.5 & 20.0 & 11.7 & 12.1 & 12.8 & 12.4 & 11.2 & 11.9 \\
\hline $\mathrm{Co}^{2+}$ & 8.3 & 9.6 & 8.7 & 7.7 & 8.7 & 6.7 & 6.2 & 6.3 & 6.0 & 6.6 & 6.2 & 6.5 \\
\hline $\mathrm{Cu}^{2+}$ & 1.6 & 2.8 & 2.8 & 3.6 & 3.0 & 3.9 & 4.8 & 3.4 & 6.2 & 4.3 & 5.2 & 5.7 \\
\hline $\mathrm{Cd}^{2+}$ & 4.4 & 4.9 & 4.5 & 3.9 & 3.4 & 4.5 & 3.6 & 3.9 & 4.1 & 4.5 & 3.2 & 3.2 \\
\hline $\mathrm{Pb}^{2+}$ & 1.3 & 0.0 & 0.0 & 0.7 & 0.7 & 1.5 & 3.4 & 1.0 & 0.9 & 0.7 & 0.7 & 0.9 \\
\hline
\end{tabular}

increasing oxygen content. All the resins $\left(\mathrm{P}_{1}-\mathrm{P}_{12}\right)$ showed a high loading capacity toward $\left(\mathrm{Cr}^{3+}\right)$ compaired to other ions under investigation $\left(\mathrm{Co}^{2+}, \mathrm{Cu}^{2+}, \mathrm{Cd}^{2+}\right.$ and $\left.\mathrm{Pb}^{2+}\right)$.

\section{Acknowledgements}

The author sincerely thank prof. Ali T. Al-Samaraie for helping to analyze (TGA) charts and to chemical engineering department-Tikrit university for great efforts to ease the analytical work on atomic absorption. Thanks are also due to Thaaer F. Khalil for recording (IR) analysis.

\section{REFERENCES}

[1] R. W. Tess and G. W. Poehlein, "Applied Polymer Science," 2nd Edition, American Chemical Society, New York, 1985.

[2] R. R. Gontea and K. Balasubramanian, "Chemically Modified Polymer Beads for Sorption of Gold from Waste Gold Solution," Journal of Hazardous Materials, Vol. 217-218, 2012, pp. 217- 218.

[3] F. Gode and E. pehlivan, "A Comparative Study of Two Chelating Ion-Exchange Resins for the Removal of Chromium (III) from Aqueous Solution," Journal of Hazardous Materials, Vol. 100, No. 1-3, 2003, pp. 231-243. doi:10.1016/S0304-3894(03)00110-9

[4] R. Shemshadi1, M. Arvand, A. A. Efendiev and N. A. Zeynalov, "Application of Synthetic Polymers as Adsorbents for the Removal of Cadmium from Aqueous Solutions: Batch Experimental Studies," Caspian Journal of Environmental Sciences, Vol. 10, No. 1, 2012, pp. 1-8.

[5] F. M. Almutairia and R. W. Lovittb, "Polymer Enhanced Ultrafiltration (PEUF) for the Removal of Metals from Water: Influence of Competing Solutes and Chelators," International Journal of Chemical and Environmental Engineering, Vol. 3, No. 2, 2012, pp. 15-22.

[6] A. A. Atia, A. M. Donia and K. Z. Elwakeel, "Selective Separation of Mercury (II) Using a Synthetic Resin Containing Amine and Mercaptan as Chelating Groups," Re- active and Functional Polymers, Vol. 65, No. 3, 2005, pp. 267-275. doi:10.1016/j.reactfunctpolym.2005.07.001

[7] J. D. Joshi, N. B. Patel and S. D. Patel, "Synthesis, Characterization and Ion-Exchange Study of Poly (2,4-Dihyroxy Benzo Phenone) Butylenes Resin and Its Polychelates with Transition Metals," Iranian Polymer Journal, Vol. 15, 2006, pp. 219-226.

[8] E. P. Michael, J. M. Barbe, H. D. Juneja and L. J. Pahiw, "Synthesis, Characterization and Thermal Degradation of 8-Hydroxyguinoline-gaunidine-formaldehyde Terpolymers," European Polymer Journal, Vol. 43, No. 12, 2007, pp. 4995-5000. doi:10.1016/j.eurpolymj.2007.09.006

[9] J. Wolfrum and G. W. Ehrenstein, "Interdependence between the Curing Structures, and the Mechanical Properties of Phenolic Resins," Journal of Applied Polymer Science, Vol. 74, No. 13, 1999, pp. 3173-3185.

doi:10.1002/(SICI)1097-4628(19991220)74:13<3173::AI D-APP21>3.0.CO;2-6

[10] A. A. K. Whitehouse, E. G. K. Pritchett and G. Barnett, "Phenolic Resins," Iliffe, London, 1967.

[11] R. R. Jack and D. H. Ned, "Improved Synthesis of 5-Substituted-4-amino-3-mercapto (4H)-1,2,4-traiazoles," Journal of Heterocyclic Chemistry, Vol. 13, No. 4, 1976, pp. 925-926. doi:10.1002/jhet.5570130450

[12] S. M. Kadari, A. Sajjanshetty and K. H. Lagali, "New Methods of Synthesis of Various 2-Amino Thiadiazole, 2-Mercapto Triazole 1,2-Diamino Triazole Derivatives and Their Biological Activities," Indian Journal of Heterocyclic Chemistry, Vol. 1, 1992, pp. 221-224.

[13] C. Narendra, R. Ametaa, R. Ametab and S. Ameta, "Synthesis and Characterization of p-Hydroxybenzaldehyde Oxime Based Terpolymers and Their Biological Activities," Malaysian Polymer Journal, Vol. 5, No. 2, 2010, pp. 162-180.

[14] A. T. AL Samaraee and G. A. Adam, "Synthesis, Characterisation and Analytical Study of Some New Chelating Resins as Foams, Supported Thermosets and IPNS," $\mathrm{Na}$ tional Journal of Chemistry, Vol. 1, 2001, pp. 158-171.

[15] V. V. Korshak, "The Chemical Structure and Thermal Characteristics of Polymers," Halsted Press, New York, 1971. 